\title{
Use of Clay Minerals to Control Radioactive Cesium Leaching from Municipal Solid Waste Incineration Ash in Fukushima Prefecture in Summer and Winter
}

\author{
Naoharu Murasawa ${ }^{1,2, *}$ and Tamao Hatta ${ }^{2}$ \\ 1 Fukushima Prefectural Center for Environmental Creation, 10-2 Fukasaku, Miharu-machi 963-7700, \\ Fukushima, Japan \\ 2 Faculty of Risk and Crisis Management, Chiba Institute of Science, 3 Shiomi-Cho, Choshi 288-0025, Chiba, \\ Japan; thatta@cis.ac.jp \\ * Correspondence: n-murasawa@cis.ac.jp; Tel.: +81-0479-30-4500
}

check for

updates

Citation: Murasawa, N.; Hatta, T. Use of Clay Minerals to Control Radioactive Cesium Leaching from Municipal Solid Waste Incineration Ash in Fukushima Prefecture in Summer and Winter. Pollutants 2021, 1, 253-269. https://doi.org/10.3390/ pollutants 1040020

Academic Editor: María Ángeles Martín-Lara

Received: 26 July 2021

Accepted: 26 November 2021

Published: 3 December 2021

Publisher's Note: MDPI stays neutral with regard to jurisdictional claims in published maps and institutional affiliations.

Copyright: (C) 2021 by the authors. Licensee MDPI, Basel, Switzerland. This article is an open access article distributed under the terms and conditions of the Creative Commons Attribution (CC BY) license (https:// creativecommons.org/licenses/by/ $4.0 /)$.

\begin{abstract}
Radioactive cesium (r-Cs) released from the 2011 Fukushima Daiichi Nuclear Power Plant attaches to vegetation/soil and is collected as municipal solid waste (MSW) for incineration, being concentrated in incineration ash (bottom ash [BA], fly ash [FA], and chelate-treated FA [TFA]). r-Cs in FA and TFA can easily leach upon contact with moisture. It is important to prevent further contamination, as r-Cs has negative effects on ecosystems and the human body. Naturally available clay minerals, considered effective for capturing $r-C s$, are a good alternative. Here, we sampled ash from MSW incineration facilities in Fukushima in August 2016 and February 2017. We used energy dispersive X-ray fluorescence spectroscopy and Ge semiconductor detector to determine elemental composition and r-Cs concentration in the samples and conducted leaching tests. We also determined the extent of leaching suppression by zeolite, acidic clay, and vermiculite. Chloride contents and $\mathrm{r}-\mathrm{Cs}$ leaching rates were higher in FA and TFA than in BA, regardless of the season. Prior direct addition and mixing of clay minerals (5 to $20 \mathrm{wt}$.\%) effectively prevented r-Cs leaching. This study is the first to examine r-Cs leaching inhibition by clay mineral direct addition and mixing to MSW incineration ash.
\end{abstract}

Keywords: municipal solid waste; incineration ash; radioactive Cs; leaching properties; clay minerals; safety measures

\section{Introduction}

Various radioactive substances were released into the environment during the accident at the 2011 Fukushima Daiichi Nuclear Power Plant [1-3]. Among these substances, radioactive cesium ( $\mathrm{r}-\mathrm{Cs}$ ) has the longest half-life $\left({ }^{134} \mathrm{Cs}: 2.1 \mathrm{y} ;{ }^{137} \mathrm{Cs}: 30 \mathrm{y}\right)$ and is of concern because of its effects on ecosystems and the human body [4].

Accordingly, r-Cs pollution in Fukushima Prefecture was investigated after the accident, and decontamination operations were conducted to reduce its air dose in areas where the contamination degree was significant. The decontamination waste generated by this operation was treated in a dedicated facility. However, r-Cs adhering to grass and soil tends to gather in municipal solid waste (MSW) through pruned branches, leaf litter, and daily outdoor activities of local residents (e.g., cleaning, herbicide use, and agricultural operations).

This contaminated waste is often incinerated in MSW incineration facilities [5], and the $\mathrm{r}-\mathrm{Cs}$ is concentrated in the ash because the incineration treatment does not remove it. Accordingly, r-Cs has been detected in the ash of incinerated MSW in Fukushima Prefecture.

The response measures for ash containing $r-C$ s change according to the $r-C$ s concentration [6]. In addition, $\mathrm{r}-\mathrm{C}$ s contained in fly ash (FA) and chelate-treated fly ash (TFA) leaches easily upon contact with moisture [7]. Therefore, it has been suggested that r-Cs can leach during temporary storage and after landfilling at the final disposal site [8]. 
Thus, to ensure the safety of the treatment process and promote the proper handling of this contaminant residue, it is important to ascertain the basic physical properties and $\mathrm{r}$-Cs leaching characteristics of MSW incineration ash, examine methods to control leaching, and communicate the obtained results to local residents in an easy-to-understand manner.

In this study, we investigated ash samples from five MSW incineration facilities located in Fukushima Prefecture sampling in August 2016 (summer) and February 2017 (winter) to determine differences according to season, basic physical properties, and r-Cs leaching characteristics.

We also analyzed the ability of clay minerals to capture r-Cs $[9,10]$ and examined the extent to which the leaching of $\mathrm{r}$-Cs could be suppressed by the direct addition and mixing of zeolite and vermiculite (5 to $20 \mathrm{wt}$.\%) to MSW incineration ash. In addition, we examined whether the direct addition and mixing of clay minerals could interfere with the inhibition of heavy metal leaching by chelating agents.

Previous studies have investigated the high leaching rate of r-Cs from FA and TFA and developed a method to remove r-Cs by washing FA and TFA [11]. However, this method requires the construction of washing facilities and would likely require measures to ensure safe management of contaminated water generated by the washing process. There are also chemical methods to remove or inhibit r-Cs leaching [12-14], but they can restrict the number of places where the ash can be recycled and create problems related to landfill disposal. Therefore, it would be preferable to use materials that exist in nature when trying to inhibit r-Cs leaching from MSW incineration ash, which is the reason we examined the effect of clay minerals in this study.

Some clay minerals, such as zeolites and vermiculite, have been investigated for their ability to capture r-Cs [15-18]. However, only few studies have analyzed the inhibition of $\mathrm{r}$-Cs leaching from r-Cs-contaminated MSW incineration ash by direct adding and mixing clay minerals, which is thought to be effective for capturing r-Cs. This study is the first to examine the extent to which r-Cs leaching can be inhibited by the direct addition and mixing of clay minerals to MSW incineration ash.

\section{Experimental}

\subsection{Samples}

Ash samples were collected from five MSW incineration facilities (Facility A-E) in Fukushima Prefecture in August 2016 (summer) and February 2017 (winter). The sampled furnaces were all of stoker type. Samples of bottom ash (BA), FA, and TFA were obtained from each furnace. BA is the residue left at the bottom of the furnace when MSW is incinerated, and it is sprayed with cooling water to extinguish the fire. FA is obtained by collecting the fine particles contained in the flue gas generated when waste is incinerated in a baghouse. TFA is obtained by adding a chelating agent to FA to suppress the leaching of heavy metals. Particles with size $\leq 2 \mathrm{~mm}$ were selected using a stainless-steel sieve.

\subsection{Analysis of Sample Elemental Composition}

To investigate the elemental composition of the ash samples, energy dispersive $\mathrm{X}$-ray fluorescence (ED-XRF) spectroscopy (JSX-3220; JEOL Ltd., Tokyo, Japan) was conducted in vacuum using the bulk fundamental parameter method. The voltage was set to $30.0 \mathrm{keV}$, current was automatically set (between minimum and maximum values), and measurement time was set to $600 \mathrm{~s}$. The measured elements were $\mathrm{Na}, \mathrm{Mg}, \mathrm{Al}, \mathrm{Si}, \mathrm{P}, \mathrm{S}, \mathrm{Cl}, \mathrm{K}, \mathrm{Ca}, \mathrm{Fe}, \mathrm{Cu}$, $\mathrm{Zn}$, and $\mathrm{Pb}$. The samples were prepared using the pellet method, wherein each sample was compacted in an aluminum ring with inner diameter of $3.1 \mathrm{~cm}$ and height of $0.5 \mathrm{~cm}$ using a machine press.

\subsection{Analyses of Concentration and Leaching of $r$-Cs}

The r-Cs concentrations in the MSW ash samples were measured using a Ge semiconductor detector (GC3018 CC-HI-U; Canberra, CT, USA). Each sample was compacted in a $100 \mathrm{~mL} \mathrm{U}-8$ polypropylene container to a height of $5 \mathrm{~cm}$ and then placed in the detector. 
Measurements were performed for $1 \mathrm{~h}$ to determine the $\mathrm{r}-\mathrm{Cs}$ concentration. The measured detection limit for both ${ }^{134} \mathrm{Cs}$ and ${ }^{137} \mathrm{Cs}$ was $5 \mathrm{~Bq} / \mathrm{kg}$, and the decay correction date was considered the sampling date to calculate their concentrations. Moreover, moisture content was measured by air oven drying method (PR-2KPH; ESPEC, Tokyo, Japan).

JIS K 0058-1 leaching tests [19] were performed to investigate r-Cs leaching from the ash samples upon contact with moisture, which can occur during recycling or landfilling. Approximately $300 \mathrm{~g}$ of ash was placed in a $5 \mathrm{~L}$ polyethylene bottle, to which $3 \mathrm{~L}$ of ultrapure water was added. The mixture was stirred for $6 \mathrm{~h}$ at $200 \mathrm{rpm}$ using an agitator, and then passed through a filtration unit using a membrane filter with pore size of $0.45 \mu \mathrm{m}$. Subsequently, a $2 \mathrm{~L}$ acrylic container was filled to a height of $12 \mathrm{~cm}$ with the filtrate and placed in the Ge semiconductor detector. Measurements were performed for $6 \mathrm{~h}$ to determine the r-Cs concentration. The measured detection limit for ${ }^{134} \mathrm{Cs}$ and ${ }^{137} \mathrm{Cs}$ was $0.1 \mathrm{~Bq} / \mathrm{L}$.

The r-Cs concentrations are expressed as the sum of ${ }^{134} \mathrm{Cs}$ and ${ }^{137} \mathrm{Cs}$ concentrations. The r-Cs leaching rate was calculated using Equation (1):

$$
\text { Leaching rate }(\%)=\frac{C_{\text {Filtrate }} / \rho \times W_{\text {Filtrate }}}{C_{\text {Sample }} \times W_{\text {Sample }}} \times 100
$$

where $\mathrm{C}_{\text {Sample }}$ and $\mathrm{C}_{\text {Filtrate }}$ are the r-Cs concentrations $(\mathrm{Bq} / \mathrm{kg})$ of the sample and filtrate, respectively; $\mathrm{W}_{\text {Sample }}$ and $\mathrm{W}_{\text {Filtrate }}$ are their respective weights $(\mathrm{kg})$; and $\rho$ is the solvent density $(\rho=1.0 \mathrm{~kg} / \mathrm{L})$.

Moreover, the $\mathrm{pH}$ and electrical conductivity (EC) of the filtrate were also measured using a glass electrode-type $\mathrm{pH}$ meter and an alternating-current bipolar-type electron conductivity meter (pH: DS-52 and EC: F-52; both from Horiba, Kyoto, Japan).

\subsection{Analysis of Inhibitory Effect of Clay Minerals on $r$-Cs Leaching}

To reduce the leaching of $\mathrm{r}$-Cs upon contact with water during temporary storage and at the final disposal site, the following materials were direct added and mixing to the samples at 5, 10, and $20 \mathrm{wt} . \%$ : zeolite crushed in an agate mortar (Zeofill 60P; Shin Tohoku Chemical Industry Co., Ltd. (Miyagi, Japan); median diameter: $41.5 \mu \mathrm{m}$, specific surface area: $4084.3 \mathrm{~cm}^{2} / \mathrm{cm}^{3}$ ), acidic clay (Mizuka Catcher DX; Mizusawa Industrial Chemicals, Ltd., Tokyo, Japan; median diameter: $11.5 \mu \mathrm{m}$, specific surface area: $5555.6 \mathrm{~cm}^{2} / \mathrm{cm}^{3}$ ), vermiculite from Fukushima Prefecture (raw stone before calcining, median diameter: $17.4 \mu \mathrm{m}$, specific surface area: $3994.7 \mathrm{~cm}^{2} / \mathrm{cm}^{3}$ ), and vermiculite from India (raw stone before calcining, median diameter: $16.2 \mu \mathrm{m}$, specific surface area: $4993.2 \mathrm{~cm}^{2} / \mathrm{cm}^{3}$ ). The samples were then subjected to measurements and JIS K 0058-1 leaching tests [19] using a Ge semiconductor detector under the conditions described in Section 2.3. Equation (2) was used to determine the amount of ultrapure water required for a moisture content of $30 \%$ in the samples after the direct addition and mixing of 5-20 wt.\% clay minerals:

$$
\frac{\mathrm{M}_{\text {Sample }}+\mathrm{M}_{\text {Clay minerals }}+\mathrm{M}_{\text {Ultra pure water }}}{\mathrm{W}_{\text {Sample }}+\mathrm{W}_{\text {Clay minerals }}+\mathrm{W}_{\text {Ultra pure water }}}=0.3
$$

where $\mathrm{W}_{\text {Sample}}, \mathrm{W}_{\text {Clay minerals, }}$ and $\mathrm{W}_{\text {Ultrapure water }}$ represent the weights $(\mathrm{kg})$ of the sample, clay minerals, and ultrapure water, respectively; and $\mathrm{M}_{\text {Sample }}, \mathrm{M}_{\text {Clay minerals, }}$ and $\mathrm{M}_{\text {Ultrapure water }}$ represent their respective moisture contents $(\mathrm{kg})$. To confirm the long-term inhibitory effect on r-Cs leaching, additional leaching tests $(7,14$, and $30 \mathrm{~d})$ were conducted for $5 \mathrm{wt} . \%$ clay minerals.

\subsection{Analysis of Effect of Clay Minerals on Heavy Metal Chelation}

To elucidate whether the direct addition and mixing of clay minerals interfered with the inhibitory effect of chelating agents on heavy metal leaching, 6-h and 30-d leaching tests were conducted on TFA with and without $5 \mathrm{wt} . \%$ clay minerals, and the concentration of heavy metals in the filtrate was then measured, using an ion chromatography system (ICS- 
2000; Thermo Fisher Scientific, Waltham, MA, USA) with an inductively coupled plasma (ICP) emission spectrometer (iCAP 6300; Thermo Fisher Scientific, Waltham, MA, USA) and anion-exchange column (Dionex IonPac AS18; Thermo Fisher Scientific, Waltham, MA, USA). To perform ICP emission spectrometry, quantification was performed using a four-point calibration curve method with element standard solutions at of $0.5,5,10$, and $50 \mathrm{mg} / \mathrm{L}$. The standard solutions were prepared by diluting ICP Multi standard IV (Merch Group, Darmstadt, Germany) with $0.1 \mathrm{~mol} / \mathrm{L}$ nitric acid, and the sample solutions were diluted 10-fold also with $0.1 \mathrm{~mol} / \mathrm{L}$ nitric acid.

For ion chromatography, we used a three-point calibration curve and standard ion concentration solutions (Anion Mixture Standard Solution; FUJIFILM Wako Pure Chemical Corporation, Osaka, Japan) diluted 5-, 10-, and 50-fold with ultrapure water. To prepare the sample solution, 250- and 5000-fold dilutions with ultrapure water were employed. In addition, a potassium hydroxide aqueous solution generated from an eluent generator cartridge for anion analysis (EGC III-KOH; Thermo Fisher Scientific, Waltham, MA, USA) was used as the eluent.

\section{Results and Discussion}

\subsection{Elemental Composition of Ash Samples}

Figures 1-3 show the results of the ED-XRF analysis. There were no significant changes between samples collected in August 2016 and February 2017, which indicates that there were no changes between seasons within the same facility. The BA samples contained high concentrations of $\mathrm{Ca}, \mathrm{Si}$, and $\mathrm{Al}$, indicating that the main components were $\mathrm{CaO}, \mathrm{SiO}_{2}$, and $\mathrm{Al}_{2} \mathrm{O}_{3}[20,21]$. In contrast, the FA and TFA samples contained large amounts of $\mathrm{Ca}$, $\mathrm{Cl}$, and $\mathrm{Na}$. The $\mathrm{Ca}$ in FA and TFA was assumed to exist as $\mathrm{Ca}(\mathrm{OH})_{2}, \mathrm{CaCl}_{2}, \mathrm{CaO}$, and $\mathrm{CaSO}_{4}[22,23]$, and it was attributed to the slaked lime blown into the furnace as a measure against $\mathrm{HCl}$ gas. The $\mathrm{Na}$ in the FA and TFA existed as $\mathrm{NaCl}$ and was likely generated by the incineration of household food waste [24-26]. The $\mathrm{Cl}$ content was higher in FA and TFA than in BA, suggesting the presence of large amounts of water-soluble chlorides in FA.

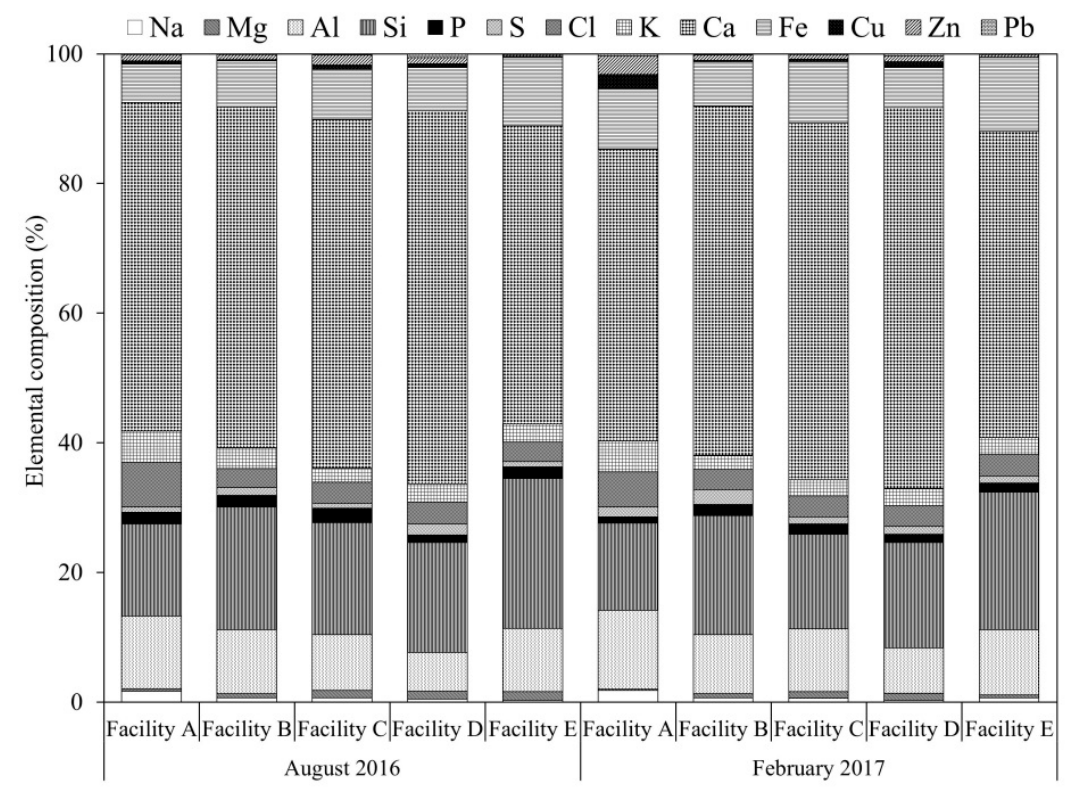

Figure 1. Elemental composition of bottom ash (BA) determined using energy dispersive X-ray fluorescence spectroscopy. 


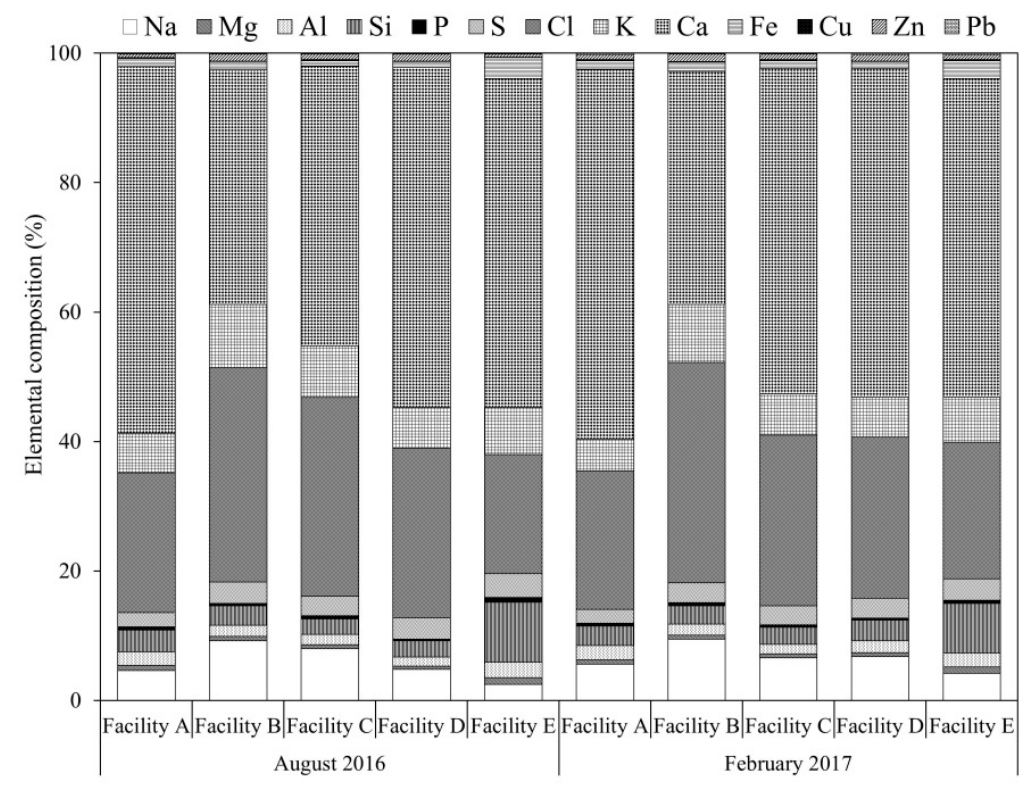

Figure 2. Elemental composition of fly ash (FA) determined using energy dispersive X-ray fluorescence spectroscopy.

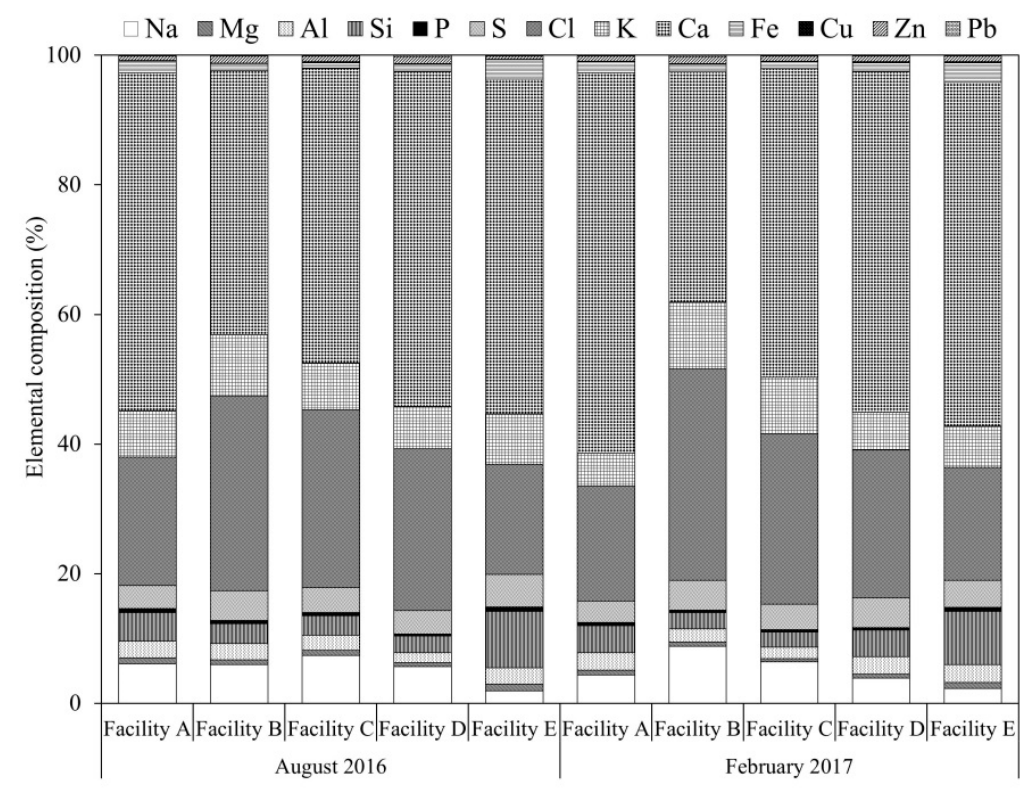

Figure 3. Elemental composition of chelate-treated fly ash determined using energy dispersive X-ray fluorescence spectroscopy.

Cs is a volatile element $[27,28]$ that can appear in BA, FA, and TFA in different forms $[21,29,30]$. Most $r-C s$ enters MSW incineration facilities via vegetation and soil and is volatilized into a gaseous state during incineration, thereby migrating into the flue gas [31]. $\mathrm{r}$-Cs cools near the baghouse filter, which is controlled at approximately $200^{\circ} \mathrm{C}$, and then solidifies and concentrates in the FA and TFA [8]. Therefore, Cs can exist in FA and TFA in the form of highly water-soluble $\mathrm{CsCl}[29,30], \mathrm{CsOH}$, and $\mathrm{Cs}_{2} \mathrm{SO}_{4}[32,33]$.

\subsection{Concentration and Leaching Properties of $r$-Cs in MSW Incineration Ash}

Table 1 (for August 2016) and Table 2 (for February 2017) show the r-Cs concentrations and leaching test results of the ash samples. If the r-Cs concentration of the filtrate was below the detection limit $(0.1 \mathrm{~Bq} / \mathrm{L})$, it was considered $0 \mathrm{~Bq} / \mathrm{L}$ and is shown as ND in 
Tables 1 and 2. The water content of the ash samples was determined using an air oven drying method and is also shown in Tables 1 and 2.

Table 1. Concentration and leaching of radioactive cesium (r-Cs) in August 2016.

\begin{tabular}{|c|c|c|c|c|c|c|c|}
\hline \multirow[b]{2}{*}{ Facility } & \multirow[b]{2}{*}{ Sample } & \multicolumn{2}{|c|}{ MSW Incineration Ash } & \multicolumn{4}{|c|}{ Leaching Test Filtrate } \\
\hline & & $\begin{array}{c}\mathrm{r}-\mathrm{Cs} \\
\text { Concentration * } \\
(\mathrm{Bq} / \mathbf{k g})\end{array}$ & $\begin{array}{c}\text { Moisture } \\
\text { Content (\%) }\end{array}$ & $\begin{array}{c}\mathrm{r}-\mathrm{Cs} \\
\text { Concentration * } \\
(\mathrm{Bq} / \mathrm{L})\end{array}$ & $\begin{array}{l}\text { Leaching } \\
\text { Rate (\%) }\end{array}$ & $\mathrm{pH}$ & $\mathrm{EC}(\mathrm{mS} / \mathrm{m})$ \\
\hline \multirow{3}{*}{$\mathrm{A}$} & BA & $587(87+500)$ & 23.2 & $1.0(0.2+0.8)$ & 1.7 & 11.6 & 367 \\
\hline & FA & $2260(360+1900)$ & 0.6 & $178(28+150)$ & 78.8 & 12.4 & 2420 \\
\hline & TFA & $2020(320+1700)$ & 14.6 & $165(25+140)$ & 81.7 & 12.6 & 1920 \\
\hline \multirow{3}{*}{ B } & BA & $258(48+210)$ & 26.4 & $\mathrm{ND}(0+0)$ & ND & 11.7 & 360 \\
\hline & FA & $1880(280+1600)$ & 1.7 & $141(21+120)$ & 75.0 & 12.5 & 3520 \\
\hline & TFA & $1430(230+1200)$ & 14.2 & $115(17+98)$ & 80.4 & 12.5 & 2820 \\
\hline \multirow{3}{*}{$\mathrm{C}$} & BA & $42(7+35)$ & 32.2 & $\mathrm{ND}(0+0)$ & ND & 11.8 & 563 \\
\hline & FA & $383(63+320)$ & 0.8 & $29(4+25)$ & 75.7 & 12.5 & 3710 \\
\hline & TFA & $250(40+210)$ & 21.5 & $19(3+16)$ & 76.0 & 12.6 & 2960 \\
\hline \multirow{3}{*}{$\mathrm{D}$} & BA & $686(96+590)$ & 32.6 & $0.2(0+0.2)$ & 0.3 & 11.8 & 200 \\
\hline & FA & $5870(870+5000)$ & 0.6 & $421(61+360)$ & 71.7 & 12.4 & 3100 \\
\hline & TFA & $4560(660+3900)$ & 18.1 & $362(52+310)$ & 79.4 & 12.6 & 2310 \\
\hline \multirow{3}{*}{$\mathrm{E}$} & BA & $3060(460+2600)$ & 27.7 & $0.6(0.1+0.5)$ & 0.2 & 11.8 & 360 \\
\hline & FA & $8600(1300+7300)$ & 0.4 & $532(82+450)$ & 61.9 & 12.5 & 3510 \\
\hline & TFA & $6260(960+5300)$ & 16.1 & $441(61+380)$ & 70.4 & 12.5 & 2620 \\
\hline
\end{tabular}

${ }^{*}{ }^{134} \mathrm{Cs}+{ }^{137} \mathrm{Cs} ; \mathrm{MSW}=$ municipal solid waste; $\mathrm{BA}=$ bottom ash; FA = fly ash; TFA = chelate-treated FA; EC = electrical conductivity; $\mathrm{ND}=$ not detected.

Table 2. Concentration and leaching of radioactive cesium (r-Cs) in February 2017.

\begin{tabular}{|c|c|c|c|c|c|c|c|}
\hline \multirow[b]{2}{*}{ Facility } & \multirow[b]{2}{*}{ Sample } & \multicolumn{2}{|c|}{ MSW Incineration Ash } & \multicolumn{4}{|c|}{ Leaching Test Filtrate } \\
\hline & & $\begin{array}{c}\mathrm{r}-\mathrm{Cs} \text { Concentration } \\
*(\mathrm{~Bq} / \mathrm{kg})\end{array}$ & $\begin{array}{c}\text { Moisture } \\
\text { Content (\%) }\end{array}$ & $\begin{array}{c}\mathrm{r}-\mathrm{Cs} \\
\text { Concentration * } \\
(\mathrm{Bq} / \mathrm{L})\end{array}$ & $\begin{array}{l}\text { Leaching } \\
\text { Rate }(\%)\end{array}$ & $\mathrm{pH}$ & $\mathrm{EC}(\mathrm{mS} / \mathrm{m})$ \\
\hline \multirow{3}{*}{ A } & BA & $63(7+56)$ & 6.9 & $0.1(0+0.1)$ & 1.6 & 11.2 & 192 \\
\hline & FA & $1030(140+890)$ & 0.8 & $79(11+68)$ & 76.7 & 12.3 & 3810 \\
\hline & TFA & $860(120+740)$ & 16.3 & $74(10+64)$ & 86 & 12.5 & 3000 \\
\hline \multirow{3}{*}{$\mathrm{B}$} & BA & $136(16+120)$ & 32.7 & $\mathrm{ND}(0+0)$ & ND & 11.6 & 290 \\
\hline & FA & $1850(250+1600)$ & 1.2 & $141(21+120)$ & 76.2 & 12.5 & 3920 \\
\hline & TFA & $1410(210+1200)$ & 15.1 & $116(16+100)$ & 82.3 & 12.5 & 3110 \\
\hline \multirow{3}{*}{$\mathrm{C}$} & BA & $94(14+80)$ & 35.2 & $\mathrm{ND}(0+0)$ & ND & 12.0 & 210 \\
\hline & FA & $642(82+560)$ & 0.1 & $44(7+37)$ & 68.5 & 12.3 & 3150 \\
\hline & TFA & $485(75+410)$ & 19.1 & $41(5+36)$ & 84.5 & 12.4 & 2610 \\
\hline \multirow{3}{*}{$\mathrm{D}$} & BA & $636(86+550)$ & 33.1 & $0.2(0+0.2)$ & 0.3 & 12.6 & 930 \\
\hline & FA & $3580(480+3100)$ & 1.0 & $277(37+240)$ & 77.4 & 12.5 & 4360 \\
\hline & TFA & $2330(330+2000)$ & 19.5 & $196(26+170)$ & 84.1 & 12.5 & 3280 \\
\hline \multirow{3}{*}{$\mathrm{E}$} & $\mathrm{BA}$ & $3600(500+3100)$ & 21.3 & $0.4(0+0.4)$ & 0.1 & 11.9 & 127 \\
\hline & FA & $11,000(1500+9500)$ & 0.6 & $676(86+590)$ & 61.5 & 12.3 & 2210 \\
\hline & TFA & $7090(990+6100)$ & 24.3 & $510(60+450)$ & 71.9 & 12.2 & 1470 \\
\hline
\end{tabular}

${ }^{*}{ }^{134} \mathrm{Cs}+{ }^{137} \mathrm{Cs} ; \mathrm{MSW}=$ municipal solid waste; $\mathrm{BA}=$ bottom ash; FA = fly ash; TFA = chelate-treated FA; EC = electrical conductivity; $\mathrm{ND}=$ not detected.

The r-Cs concentrations showed that some facilities presented higher Cs levels in August, whereas others showed higher Cs levels in February. This indicates that Cs levels were not constant throughout the year, and there were slight seasonal differences among the samples. The r-Cs concentrations in BA, FA, and TFA also showed substantial variation among the incineration facilities. This was consistent with results of previous studies, in 
which the type of waste supplied to the incinerator influenced the properties of BA, FA, and TFA [34,35].

A possible reason for the large difference between $\mathrm{r}$-Cs concentrations in samples from urban and rural MSW incineration facilities is the variations in type of waste, industrial structures, and regional characteristics. For instance, the amount of vegetation, leaf litter, and attached soil generated by agricultural work can differ depending on the location of the incineration facility.

The r-Cs concentrations tended to be higher in FA and TFA than in BA, regardless of the season. Some facilities presented higher r-Cs concentrations of filtrates in August, whereas others presented higher r-Cs concentrations in February. We believe this was influenced by the r-Cs concentration of the samples used in the leaching test.

There were no significant differences in r-Cs leaching rates in different seasons. In addition, the r-Cs leaching rate tended to be higher for FA and TFA than for BA, regardless of the season. Different forms of $\mathrm{r}-\mathrm{Cs}$ may have caused the differences in the r-Cs leaching rates $[21,29,30]$. According to previous studies, the leaching rates of $r-C s$ from ash generated during incineration of decontamination waste or sewage sludge are not typically high [8,36-38], which disagrees with our results for MSW incineration ash.

The $\mathrm{pH}$ of all filtrates was strongly alkaline. The EC values of FA and TFA were higher than that of $\mathrm{BA}$, and there was a certain correlation between $\mathrm{EC}$ and $\mathrm{r}-\mathrm{Cs}$ leaching rate. However, no correlation was observed between $\mathrm{pH}$ and $\mathrm{r}$-Cs leaching rate. Therefore, considering the difficulty in preventing $\mathrm{r}$-Cs leaching during landfilling using only chelating agents, additional measures are required to inhibit r-Cs leaching from FA and TFA, particularly for MSW incineration ash.

\subsection{Inhibitory Effect of Clay Minerals on $r$-Cs Leaching}

Tables 3-5 summarize the results obtained using BA, FA, and TFA collected from Facility A in August 2016 to confirm the suppression of r-Cs leaching upon direct addition and mixing of clay minerals.

Table 3. Concentration and leaching of radioactive cesium (r-Cs) upon direct addition and mixing of clay minerals at $5 \mathrm{wt} . \%$.

\begin{tabular}{|c|c|c|c|c|c|}
\hline \multirow[b]{2}{*}{ Sample } & \multicolumn{2}{|c|}{ MSW Incineration Ash } & \multicolumn{3}{|c|}{ Leaching Test Filtrate } \\
\hline & $\begin{array}{c}\text { r-Cs } \\
\text { Concentration * } \\
(\mathrm{Bq} / \mathrm{kg})\end{array}$ & $\begin{array}{c}\text { Moisture Content } \\
(\%)\end{array}$ & $\begin{array}{c}\mathrm{r}-\mathrm{Cs} \\
\text { Concentration * } \\
(\mathrm{Bq} / \mathrm{L})\end{array}$ & $\mathrm{pH}$ & $\begin{array}{c}\mathrm{EC} \\
(\mathrm{mS} / \mathrm{m})\end{array}$ \\
\hline Facility A BA + Zeolite 5\% & $512(72+440)$ & 29.8 & $\mathrm{ND}(0+0)$ & 11.5 & 362 \\
\hline Facility A BA + Acid clay 5\% & $520(70+450)$ & 29.9 & $0.3(0+0.3)$ & 11.5 & 306 \\
\hline $\begin{array}{c}\text { Facility A BA + Fukushima } \\
\text { vermiculite } 5 \%\end{array}$ & $516(66+450)$ & 29.9 & $0.2(0+0.2)$ & 11.5 & 368 \\
\hline Facility A BA + India vermiculite 5\% & $516(76+440)$ & 30.1 & $\mathrm{ND}(0+0)$ & 11.6 & 388 \\
\hline Facility A FA + Zeolite 5\% & $1530(230+1300)$ & 29.9 & $20(3+17)$ & 12.5 & 2710 \\
\hline Facility A FA + Acid clay 5\% & $1450(250+1200)$ & 30.2 & $47(7+40)$ & 12.4 & 2530 \\
\hline $\begin{array}{c}\text { Facility A FA + Fukushima } \\
\text { vermiculite } 5 \%\end{array}$ & $1520(220+1300)$ & 30.0 & $60(9+51)$ & 12.5 & 2640 \\
\hline Facility A FA + India vermiculite 5\% & $1540(240+1300)$ & 30.1 & $42(6+36)$ & 12.5 & 2660 \\
\hline Facility A TFA + Zeolite 5\% & $1650(250+1400)$ & 30.0 & $21(3+18)$ & 12.5 & 1940 \\
\hline Facility A TFA + Acid clay 5\% & $1550(250+1300)$ & 30.1 & $40(6+34)$ & 12.4 & 1520 \\
\hline $\begin{array}{c}\text { Facility A TFA + Fukushima } \\
\text { vermiculite } 5 \%\end{array}$ & $1660(260+1400)$ & 29.9 & $50(9+41)$ & 12.3 & 1690 \\
\hline Facility A TFA + India vermiculite 5\% & $1580(280+1300)$ & 29.8 & $29(5+24)$ & 12.3 & 1440 \\
\hline
\end{tabular}

${ }^{*}{ }^{134} \mathrm{Cs}+{ }^{137} \mathrm{Cs}$; MSW = municipal solid waste; $\mathrm{BA}=$ bottom ash; FA = fly ash; TFA = chelate-treated FA; EC = electrical conductivity; $\mathrm{ND}=$ not detected. 
Table 4. Concentration and leaching of radioactive cesium (r-Cs) upon direct addition and mixing of clay minerals at 10 wt.\%.

\begin{tabular}{|c|c|c|c|c|c|}
\hline \multirow[b]{2}{*}{ Sample } & \multicolumn{2}{|c|}{ MSW Incineration Ash } & \multicolumn{3}{|c|}{ Leaching Test Filtrate } \\
\hline & $\begin{array}{c}\mathrm{r}-\mathrm{Cs} \\
\text { Concentration * } \\
(\mathrm{Bq} / \mathbf{k g})\end{array}$ & $\begin{array}{c}\text { Moisture Content } \\
(\%)\end{array}$ & $\begin{array}{c}\text { r-Cs } \\
\text { Concentration * } \\
(\mathrm{Bq} / \mathrm{L})\end{array}$ & $\mathrm{pH}$ & $\begin{array}{c}\mathrm{EC} \\
(\mathrm{mS} / \mathrm{m})\end{array}$ \\
\hline Facility A BA + Zeolite 10\% & $468(68+400)$ & 30.1 & $\mathrm{ND}(0+0)$ & 11.6 & 354 \\
\hline Facility A BA + Acid clay $10 \%$ & $467(67+400)$ & 29.8 & $0.2(0+0.2)$ & 11.3 & 339 \\
\hline $\begin{array}{c}\text { Facility A BA + Fukushima } \\
\text { vermiculite } 10 \%\end{array}$ & $488(78+410)$ & 29.7 & $\mathrm{ND}(0+0)$ & 11.5 & 387 \\
\hline Facility A BA + India vermiculite $10 \%$ & $480(70+410)$ & 30.3 & $\mathrm{ND}(0+0)$ & 11.6 & 395 \\
\hline Facility A FA + Zeolite 10\% & $1430(230+1200)$ & 30.1 & $10(2+8)$ & 12.5 & 2680 \\
\hline Facility A FA + Acid clay $10 \%$ & $1400(200+1200)$ & 29.9 & $33(5+28)$ & 12.5 & 2820 \\
\hline $\begin{array}{c}\text { Facility A FA + Fukushima } \\
\text { vermiculite } 10 \%\end{array}$ & $1410(210+1200)$ & 29.8 & $43(7+36)$ & 12.5 & 2690 \\
\hline Facility A FA + India vermiculite $10 \%$ & $1450(250+1200)$ & 30.0 & $31(4+27)$ & 12.5 & 2820 \\
\hline Facility A TFA + Zeolite 10\% & $1510(210+1300)$ & 29.9 & $7(2+5)$ & 12.5 & 2020 \\
\hline Facility A TFA + Acid clay $10 \%$ & $1530(230+1300)$ & 30.0 & $25(4+21)$ & 12.3 & 1650 \\
\hline $\begin{array}{c}\text { Facility A TFA + Fukushima } \\
\text { vermiculite } 10 \%\end{array}$ & $1490(190+1300)$ & 30.1 & $15(3+12)$ & 12.4 & 1780 \\
\hline Facility A TFA + India vermiculite $10 \%$ & $1530(230+1300)$ & 29.8 & $18(2+16)$ & 12.5 & 1510 \\
\hline
\end{tabular}

${ }^{* 134} \mathrm{Cs}+{ }^{137} \mathrm{Cs}$; MSW = municipal solid waste; BA = bottom ash; FA = fly ash; TFA = chelate-treated FA; EC = electrical conductivity; $\mathrm{ND}=$ not detected.

Table 5. Concentration and leaching of radioactive cesium (r-Cs) upon direct addition and mixing of clay minerals at 20 wt.\%.

\begin{tabular}{|c|c|c|c|c|c|}
\hline \multirow[b]{2}{*}{ Sample } & \multicolumn{2}{|c|}{ MSW Incineration Ash } & \multicolumn{3}{|c|}{ Leaching Test Filtrate } \\
\hline & $\begin{array}{c}\mathrm{r}-\mathrm{Cs} \\
\text { Concentration * } \\
(\mathrm{Bq} / \mathbf{k g})\end{array}$ & $\begin{array}{c}\text { Moisture Content } \\
(\%)\end{array}$ & $\begin{array}{c}\text { r-Cs } \\
\text { Concentration * } \\
(\mathrm{Bq} / \mathrm{L})\end{array}$ & $\mathrm{pH}$ & $\begin{array}{c}\mathrm{EC} \\
(\mathrm{mS} / \mathrm{m})\end{array}$ \\
\hline Facility A BA + Zeolite 20\% & $446(66+380)$ & 30.0 & $\mathrm{ND}(0+0)$ & 11.5 & 382 \\
\hline Facility A BA + Acid clay $20 \%$ & $451(71+380)$ & 30.1 & $\mathrm{ND}(0+0)$ & 11.4 & 387 \\
\hline $\begin{array}{c}\text { Facility A BA + Fukushima } \\
\text { vermiculite } 20 \%\end{array}$ & $461(61+400)$ & 30.0 & $\mathrm{ND}(0+0)$ & 11.6 & 396 \\
\hline Facility A BA + India vermiculite $20 \%$ & $455(65+390)$ & 29.9 & $\mathrm{ND}(0+0)$ & 11.6 & 413 \\
\hline Facility A FA + Zeolite $20 \%$ & $1300(200+1100)$ & 29.8 & $4(0+4)$ & 12.5 & 2650 \\
\hline Facility A FA + Acid clay $20 \%$ & $1290(190+1100)$ & 30.0 & $16(2+14)$ & 12.5 & 2750 \\
\hline $\begin{array}{c}\text { Facility A FA + Fukushima } \\
\text { vermiculite } 20 \%\end{array}$ & $1310(210+1100)$ & 30.2 & $21(4+17)$ & 12.5 & 2580 \\
\hline Facility A FA + India +vermiculite $20 \%$ & $1320(220+1100)$ & 29.8 & $12(2+10)$ & 12.5 & 2660 \\
\hline Facility A TFA + Zeolite 20\% & $1310(210+1100)$ & 29.9 & $2(0+2)$ & 12.5 & 2080 \\
\hline Facility A TFA + Acid clay $20 \%$ & $1300(200+1100)$ & 29.8 & $5(1+4)$ & 12.4 & 1790 \\
\hline $\begin{array}{c}\text { Facility A TFA + Fukushima } \\
\text { vermiculite } 20 \%\end{array}$ & $1280(180+1100)$ & 30.1 & $2(0+2)$ & 12.5 & 1840 \\
\hline Facility A TFA + India vermiculite $20 \%$ & $1360(260+1100)$ & 30.0 & $8(2+6)$ & 12.5 & 1630 \\
\hline
\end{tabular}

${ }^{*}{ }^{134} \mathrm{Cs}+{ }^{137} \mathrm{Cs}$; MSW = municipal solid waste; $\mathrm{BA}=$ bottom ash; FA = fly ash; TFA = chelate-treated FA; EC = electrical conductivity; $\mathrm{ND}=$ not detected.

Based on the results shown in Tables 3-5, we calculated the r-Cs leaching rates, and the main changes in $\mathrm{r}-\mathrm{Cs}$ leaching rate with respect to $\mathrm{wt} . \%$ of clay minerals is shown in Tables 6-8.

Tables 3-8 indicate that the direct addition and mixing of clay minerals suppressed the leaching of $\mathrm{r}-\mathrm{Cs}$ from all the samples. In addition, this inhibition effect was enhanced with increasing proportion (wt.\%) of clay minerals. However, the direct addition and mixing of clay minerals would also increase the total amount of waste destined for landfills or storage 
sites (Figure 4). Therefore, we proposed a maximum limit of $20 \mathrm{wt} . \%$ of clay minerals. The results show that the inhibition effect on $\mathrm{r}-\mathrm{Cs}$ leaching could be achieved by $5 \mathrm{wt} . \%$ of clay minerals, which reduced the r-Cs leaching rate to less than half the original value. Subsequently, we investigated whether the leaching of $\mathrm{r}$-Cs could be suppressed over a long period when $5 \mathrm{wt}$.\% clay minerals (Table 3) was used.

Table 6. Changes in radioactive cesium (r-Cs) leaching rate according to wt.\% of clay minerals (bottom ash, BA).

\begin{tabular}{ccccc}
\hline \multirow{2}{*}{ Sample } & \multicolumn{3}{c}{ r-Cs Leaching Rate (\%) } \\
\cline { 2 - 5 } & No Added & $\mathbf{5} \mathbf{w t} . \%$ & $\mathbf{1 0} \mathbf{w t} \%$ & $\mathbf{2 0} \mathbf{w t . \%}$ \\
\hline Facility A BA + Zeolite & ND & ND & ND \\
Facility A BA + Acid clay & 1.7 & 0.6 & 0.4 & ND \\
Facility A BA + Fukushima vermiculite & 0.4 & ND & ND \\
Facility A BA + India vermiculite & & ND & ND & ND \\
\hline
\end{tabular}

Table 7. Changes in radioactive cesium (r-Cs) leaching rate according to wt.\% of clay minerals (fly ash, FA).

\begin{tabular}{ccccc}
\hline \multirow{2}{*}{ Sample } & \multicolumn{3}{c}{ r-Cs Leaching Rate (\%) } \\
\cline { 2 - 5 } & No Added & $\mathbf{5}$ wt.\% & $\mathbf{1 0}$ wt.\% & $\mathbf{2 0}$ wt.\% \\
\hline Facility A FA + Zeolite & 13.1 & 7.0 & 3.1 \\
Facility A FA + Acid clay & 78.8 & 32.4 & 23.6 & 12.4 \\
Facility A FA + Fukushima vermiculite & 39.5 & 30.5 & 16.0 \\
Facility A FA + India vermiculite & & 27.3 & 21.4 & 9.1 \\
\hline
\end{tabular}

Table 8. Changes in radioactive cesium ( $r-C s$ ) leaching rate according to wt.\% of clay minerals (chelate-treated fly ash, TFA).

\begin{tabular}{ccccc}
\hline \multirow{2}{*}{ Sample } & \multicolumn{3}{c}{ r-Cs Leaching Rate (\%) } \\
\cline { 2 - 5 } & No Added & $\mathbf{5}$ wt.\% & $\mathbf{1 0} \mathbf{w t} . \%$ & $\mathbf{2 0} \mathbf{w t} . \%$ \\
\hline Facility A TFA + Zeolite & 12.7 & 4.6 & 1.5 \\
Facility A TFA + Acid clay & 25.8 & 16.3 & 3.8 \\
Facility A TFA + Fukushima vermiculite & 81.7 & 30.1 & 10.1 & 1.6 \\
Facility A TFA + India vermiculite & & 18.4 & 11.8 & 5.9 \\
\hline
\end{tabular}

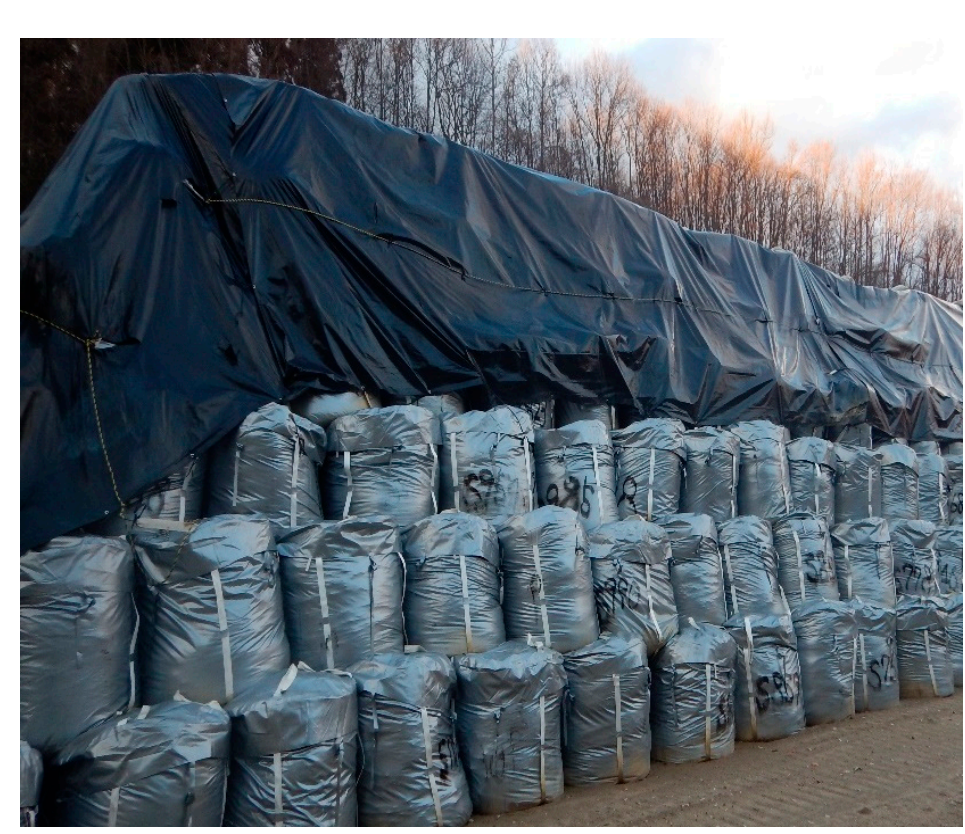

Figure 4. Example of temporary ash storage conditions in a municipal solid waste incineration facility. 
Tables 9-11 show the r-Cs concentrations of the filtrates obtained using the leaching tests. For comparison, the same conditions were applied to test samples without the direct addition and mixing of clay minerals.

Table 9. Radioactive cesium (r-Cs) leaching test results (bottom ash, BA +5 wt. $\%$ clay minerals).

\begin{tabular}{|c|c|c|c|c|}
\hline \multirow{2}{*}{ Sample } & \multicolumn{4}{|c|}{ r-Cs Concentration * $(\mathrm{Bq} / \mathrm{L})$} \\
\hline & $6 \mathrm{~h}$ & $7 \mathrm{~d}$ & $14 \mathrm{~d}$ & $30 \mathrm{~d}$ \\
\hline Facility A BA & $1.0(0.2+0.8)$ & $1.0(0.2+0.8)$ & $0.9(0.1+0.8)$ & $1.2(0.3+0.9)$ \\
\hline Facility A BA + Zeolite 5\% & ND $(0+0)$ & $\mathrm{ND}(0+0)$ & $\mathrm{ND}(0+0)$ & $0.1(0+0.1)$ \\
\hline Facility A BA + Acid clay $5 \%$ & $0.3(0+0.3)$ & $0.4(0+0.4)$ & $0.4(0+0.4)$ & $0.4(0+0.4)$ \\
\hline Facility A BA + Fukushima vermiculite 5\% & $0.2(0+0.2)$ & $0.2(0+0.2)$ & $0.2(0+0.2)$ & $0.2(0+0.2)$ \\
\hline Facility A BA + India vermiculite 5\% & $\mathrm{ND}(0+0)$ & $\mathrm{ND}(0+0)$ & $\mathrm{ND}(0+0)$ & $\mathrm{ND}(0+0)$ \\
\hline
\end{tabular}

$$
{ }^{* 134} \mathrm{Cs}+{ }^{137} \mathrm{Cs} \text {. }
$$

Table 10. Radioactive cesium (r-Cs) leaching test results (fly ash, FA + $5 \mathrm{wt} \%$ clay minerals).

\begin{tabular}{|c|c|c|c|c|}
\hline \multirow{2}{*}{ Sample } & \multicolumn{4}{|c|}{$\mathrm{r}-\mathrm{Cs}$ Concentration * (Bq/L) } \\
\hline & $6 \mathrm{~h}$ & $7 \mathrm{~d}$ & $14 \mathrm{~d}$ & $30 \mathrm{~d}$ \\
\hline Facility A FA & $178(28+150)$ & $199(39+160)$ & $201(41+160)$ & $201(41+160)$ \\
\hline Facility A FA + Zeolite 5\% & $20(3+17)$ & $19(3+16)$ & $19(3+16)$ & $25(4+21)$ \\
\hline Facility A FA + Acid clay 5\% & $47(7+40)$ & $50(8+42)$ & $50(8+42)$ & $55(9+46)$ \\
\hline Facility A FA + Fukushima vermiculite 5\% & $60(9+51)$ & $61(9+52)$ & $64(10+54)$ & $63(10+53)$ \\
\hline Facility A FA + India vermiculite 5\% & $42(6+36)$ & $44(6+38)$ & $42(6+36)$ & $45(6+39)$ \\
\hline
\end{tabular}

Table 11. Radioactive cesium ( $\mathrm{r}-\mathrm{Cs}$ ) leaching test results (chelate-treated fly ash, TFA + $5 \mathrm{wt}$ \% clay minerals).

\begin{tabular}{ccccc}
\hline Sample & \multicolumn{3}{c}{ r-Cs Concentration * (Bq/L) } \\
\cline { 2 - 5 } & $\mathbf{6 h}$ & $\mathbf{7 ~ d ~}$ & $\mathbf{1 4} \mathbf{~ d ~}$ & $\mathbf{3 0 ~ d}$ \\
\hline Facility A TFA & $165(25+140)$ & $175(25+150)$ & $189(29+160)$ & $190(30+160)$ \\
Facility A TFA + Zeolite 5\% & $21(3+18)$ & $27(4+23)$ & $37(6+31)$ & $40(6+34)$ \\
Facility A TFA + Acid clay 5\% & $40(6+34)$ & $42(7+35)$ & $45(7+38)$ & $44(6+38)$ \\
Facility A TFA + Fukushima vermiculite 5\% & $50(9+41)$ & $45(8+37)$ & $42(7+35)$ & $43(7+36)$ \\
Facility A TFA + India vermiculite 5\% & $29(5+24)$ & $27(4+23)$ & $26(4+22)$ & $26(4+22)$ \\
\hline
\end{tabular}

Figures $5 \mathrm{a}-\mathrm{d}, 6 \mathrm{a}-\mathrm{d}$ and $7 \mathrm{a}-\mathrm{d}$ show the $\mathrm{r}-\mathrm{C}$ s leaching rates calculated based on the results in Tables 9-11, and the changes in the $\mathrm{r}-\mathrm{C}$ s leaching rate with respect to time.

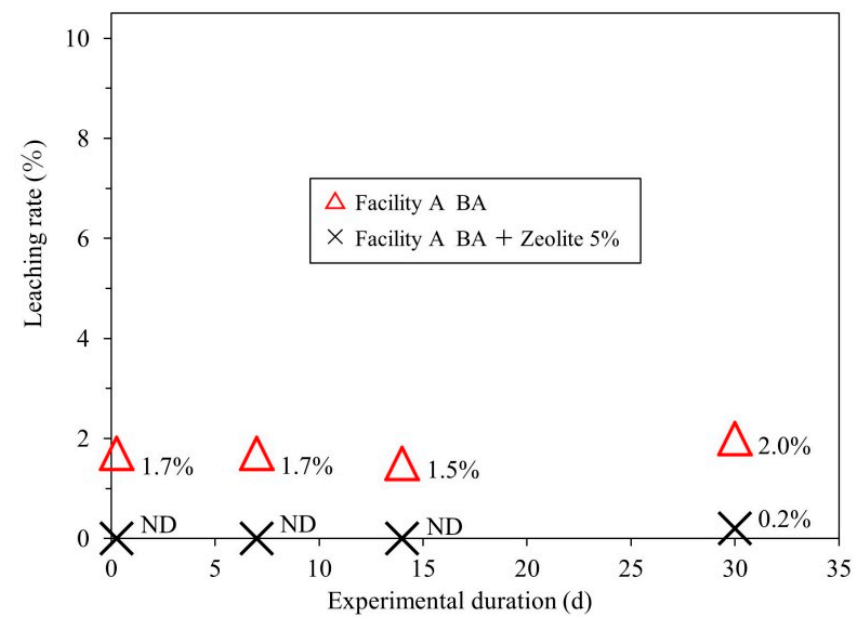

(a)

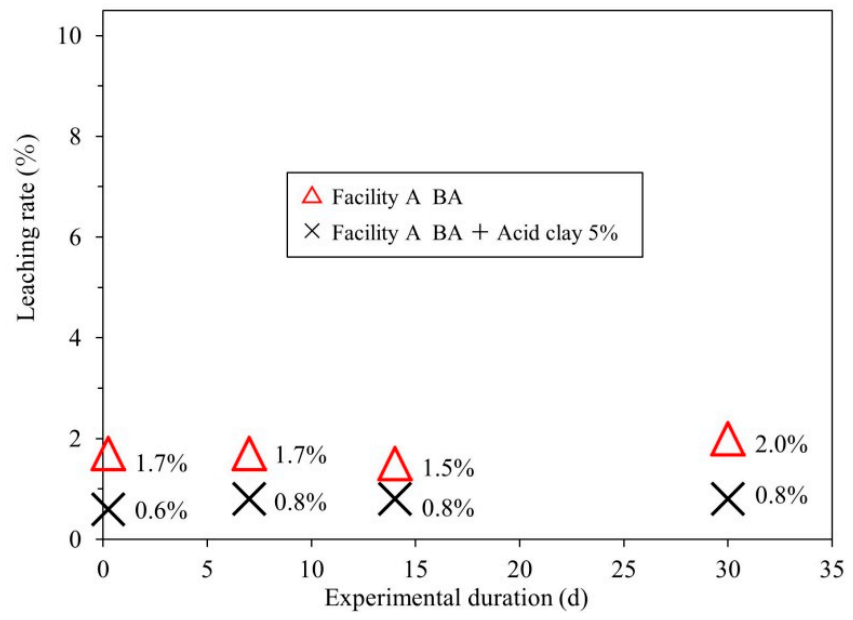

(b)

Figure 5. Cont. 


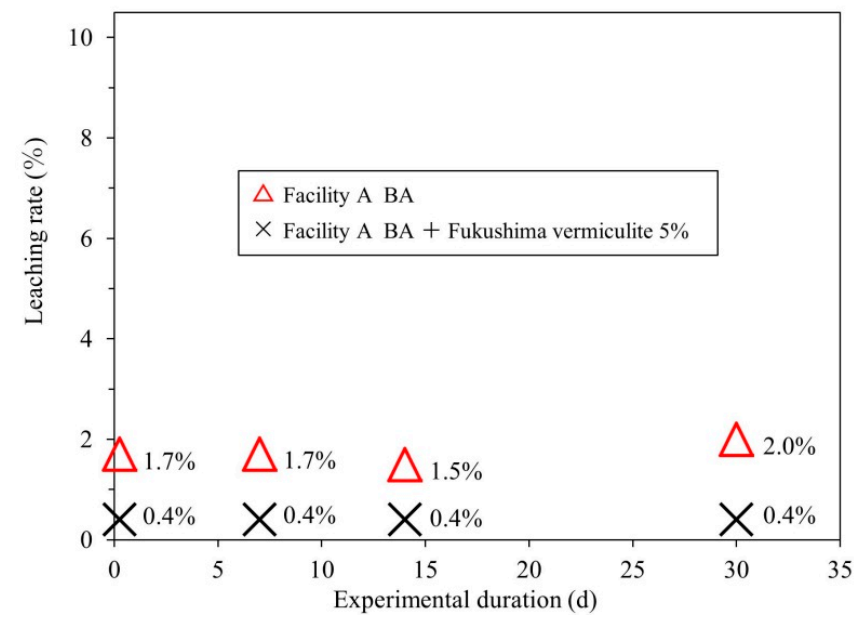

(c)

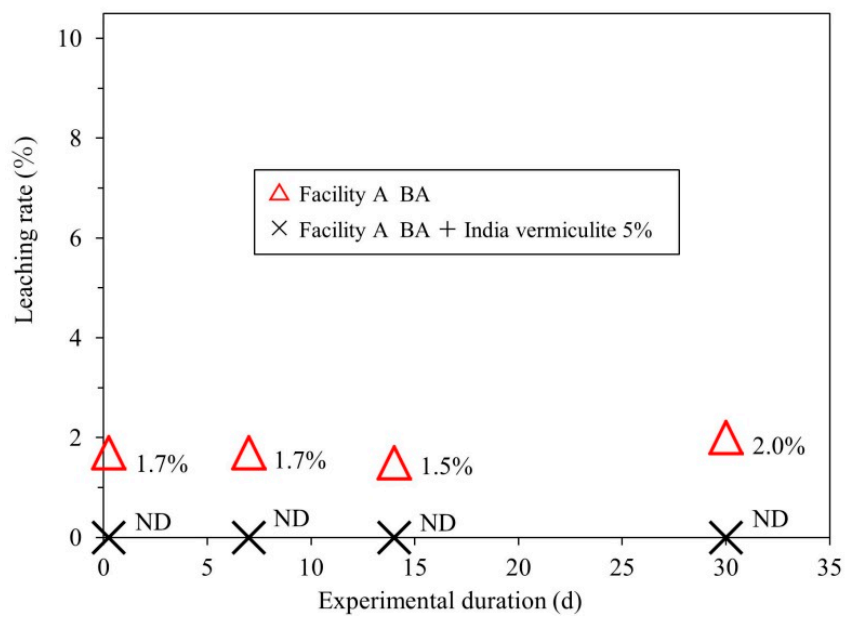

(d)

Figure 5. Changes in radioactive cesium leaching rate with respect to time (bottom ash, BA): (a) Zeolite; (b) Acid clay; (c) Fukushima vermiculite; (d) India vermiculite.

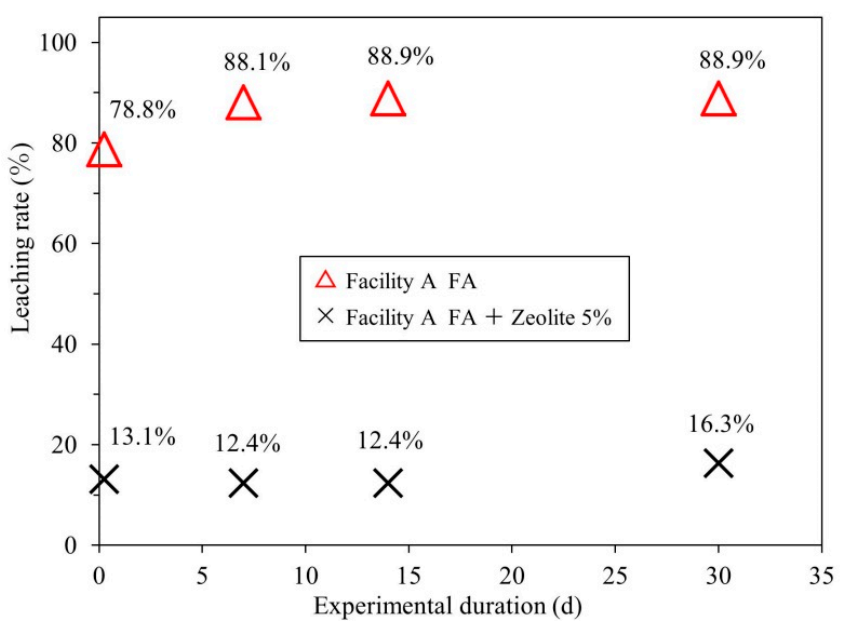

(a)

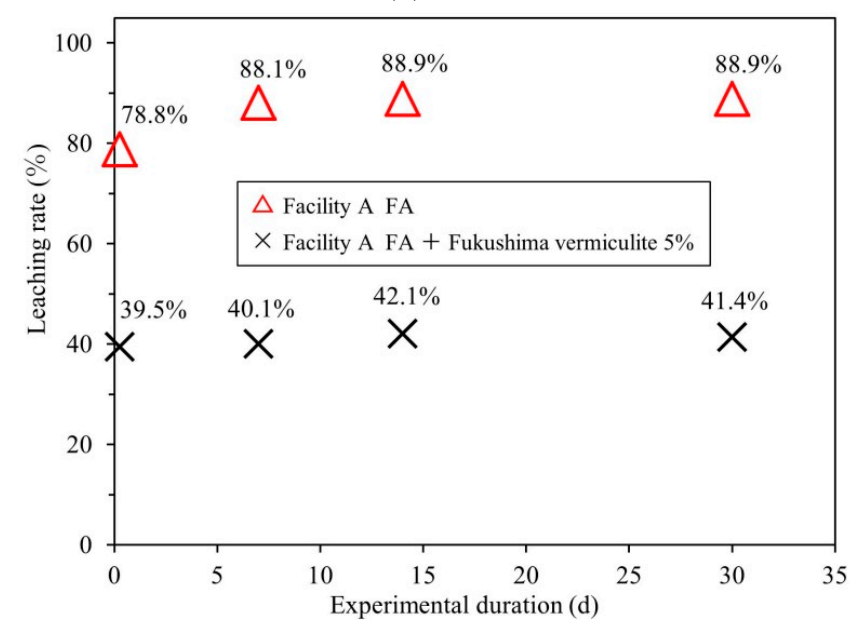

(c)

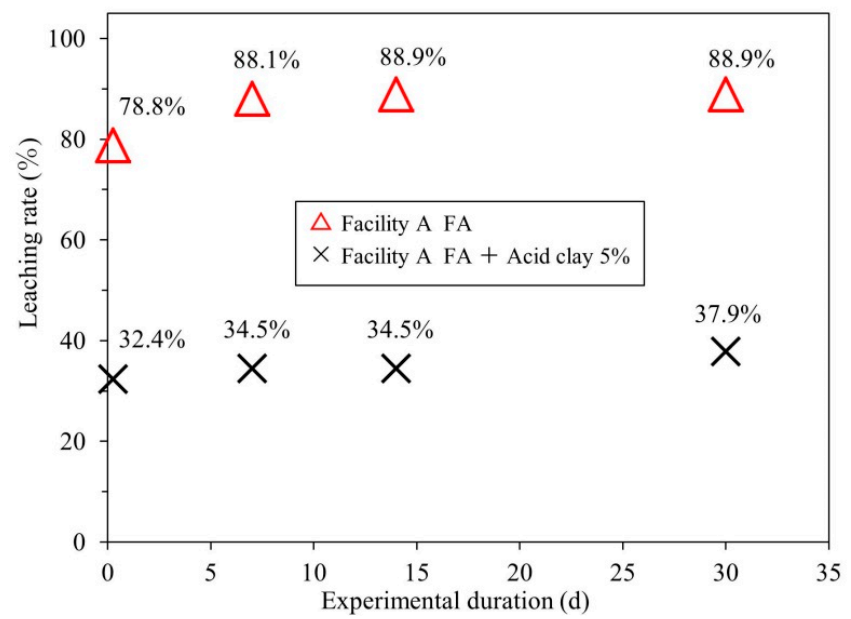

(b)

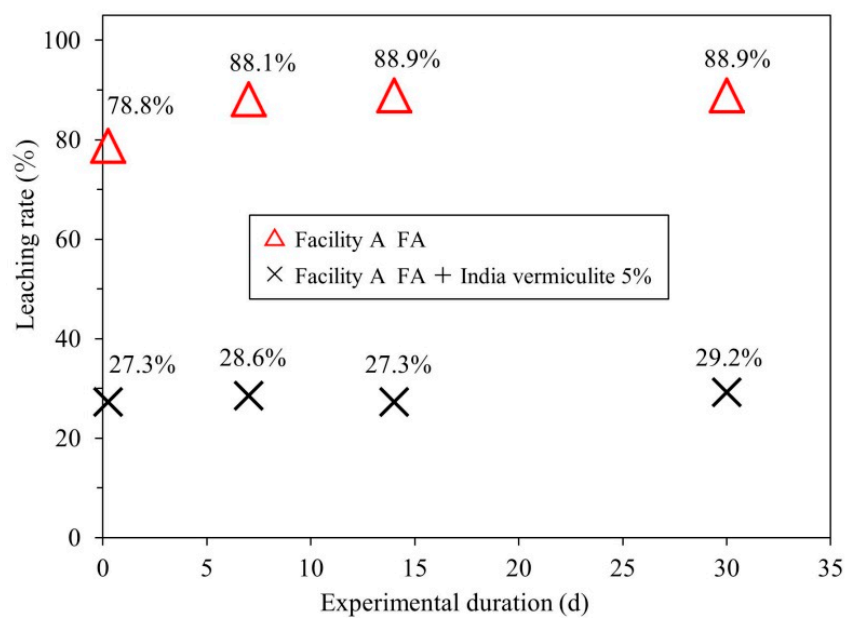

(d)

Figure 6. Changes in radioactive cesium leaching rate with respect to time (fly ash, FA): (a) Zeolite; (b) Acid clay; (c) Fukushima vermiculite; (d) India vermiculite. 


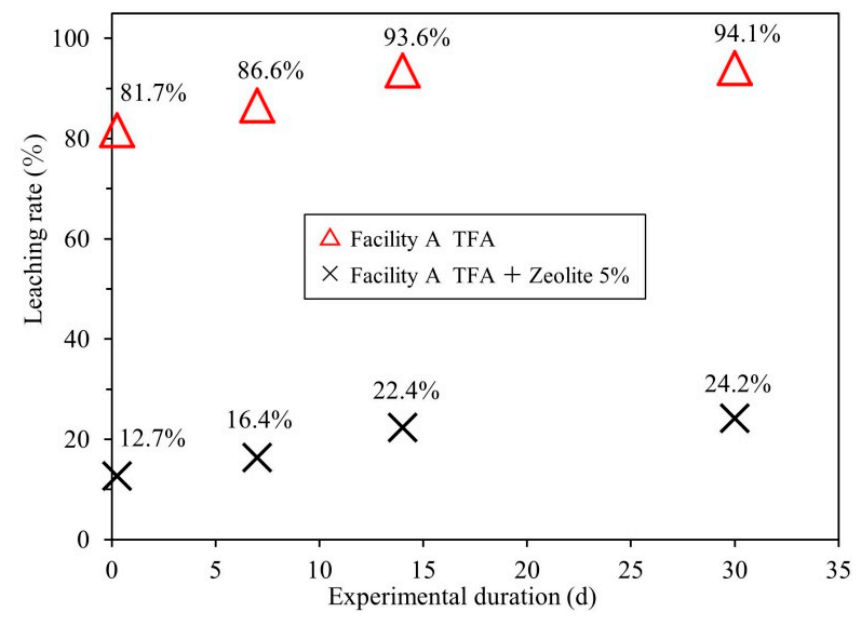

(a)

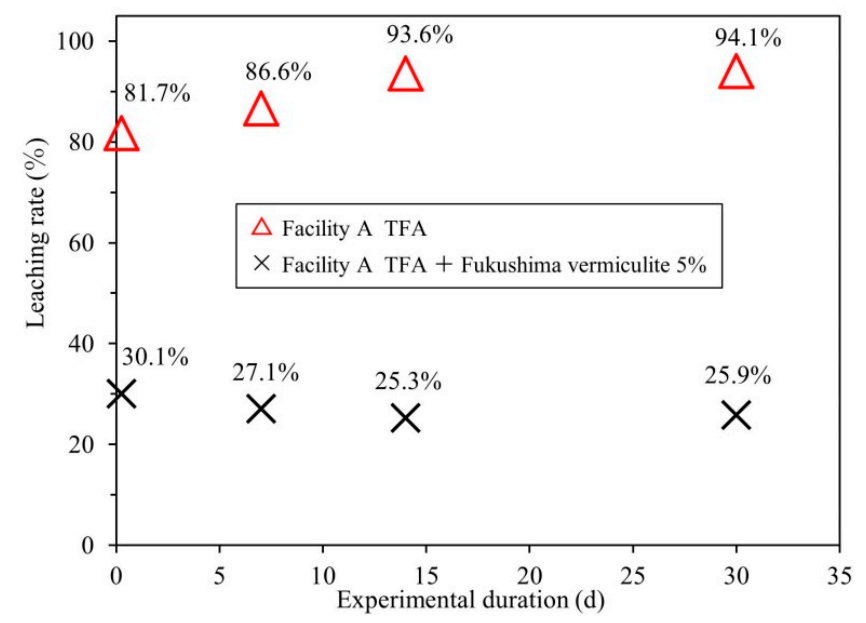

(c)

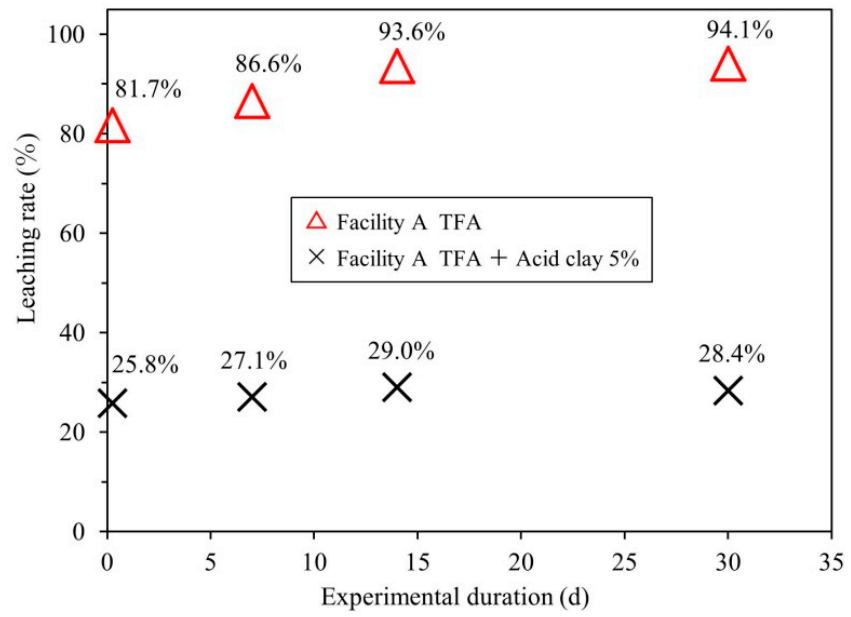

(b)

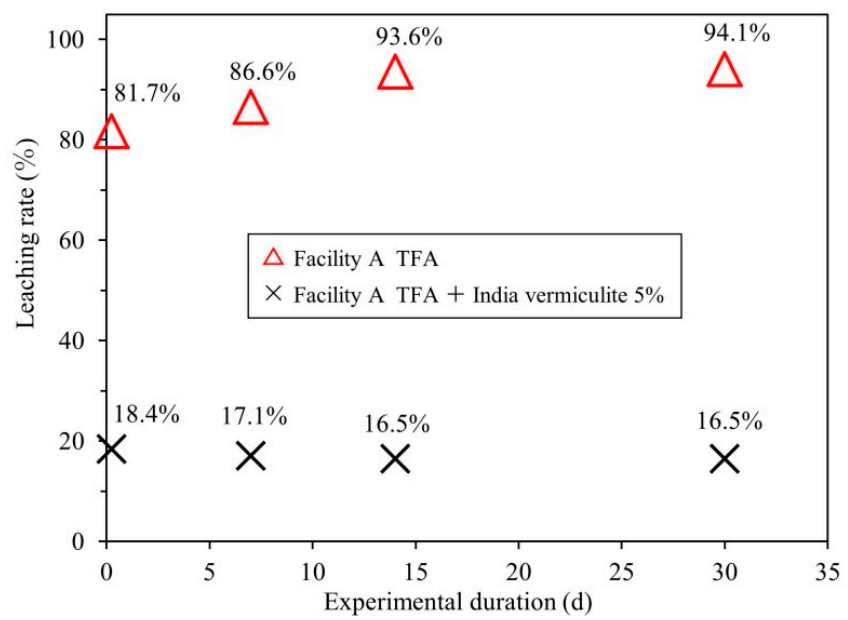

(d)

Figure 7. Changes in radioactive cesium leaching rate with respect to time (chelate-treated fly ash, TFA): (a) Zeolite; (b) Acid clay; (c) Fukushima vermiculite; (d) India vermiculite.

$\mathrm{r}-\mathrm{C}$ leaching rate did not rapidly increase in any of the samples during the tests, which demonstrated the long-term inhibition of $\mathrm{r}-\mathrm{Cs}$ leaching. Furthermore, depending on the clay mineral direct added and mixing, the $\mathrm{r}-\mathrm{C}$ s leaching rate increased gradually over the test period, which was attributed to the influence of the various ions in the filtrate [39-41].

\subsection{Effect of Clay Minerals on Heavy Metal Chelation}

Tables 12 and 13 show the results of the tests conducted on TFA samples collected from Facility A in August 2016 with and without the direct addition and mixing of 5 wt.\% clay minerals for leaching tests of $6 \mathrm{~h}$ and $30 \mathrm{~d}$, respectively. The tables also show the concentrations of heavy metals in the filtrate. For comparison, leaching tests were also performed with only clay minerals to confirm that the heavy metal concentrations in the filtrate were indeed attributed to the clay minerals. An en dash (-) is used to indicate heavy metal concentrations below the quantification limit (shown in the bottom rows of Tables 12 and 13). 
Table 12. Leaching test results indicating the effect of clay minerals on the chelating effect $(6 \mathrm{~h})$.

\begin{tabular}{|c|c|c|c|c|c|c|c|c|c|c|c|c|}
\hline \multirow{2}{*}{ Sample } & \multicolumn{12}{|c|}{ Element (mg/L) } \\
\hline & $\mathrm{Na}$ & $\mathbf{K}$ & $\mathrm{Ca}$ & Fe & $\mathrm{Cu}$ & $\mathrm{Zn}$ & $\mathbf{P b}$ & $\mathrm{Hg}$ & $\mathrm{Cd}$ & $\mathrm{Cr}$ & As & $\mathrm{Cl}^{-}$ \\
\hline \multirow{5}{*}{$\begin{array}{c}\text { Facility A TFA } \\
\text { Facility A TFA + Zeolite 5\% } \\
\text { Facility A TFA + Acid clay 5\% } \\
\text { Facility A TFA + Fukushima } \\
\text { vermiculite 5\% } \\
\text { Facility A TFA + India } \\
\text { vermiculite 5\% }\end{array}$} & 1300 & 2200 & 2800 & - & - & 0.02 & 0.03 & - & - & 0.01 & - & 8100 \\
\hline & 1300 & 1700 & 1500 & - & - & - & - & - & - & - & - & 6200 \\
\hline & 1100 & 1500 & 1300 & - & - & - & - & - & - & - & - & 5600 \\
\hline & 1100 & 1700 & 1800 & - & - & - & - & - & - & - & - & 5900 \\
\hline & 1200 & 1700 & 1800 & - & - & - & - & - & - & - & - & 6000 \\
\hline Zeolite & 7.7 & 1.0 & 12 & - & - & - & - & - & - & - & - & - \\
\hline Acid clay & 3.4 & 3.3 & 2.7 & - & - & - & - & - & - & - & - & - \\
\hline Fukushima vermiculite & 0.9 & 0.4 & 2.5 & - & - & - & - & - & - & - & - & - \\
\hline India vermiculite & 5.1 & 10.0 & 9.7 & - & - & - & - & - & - & - & - & - \\
\hline Quantification limit & 0.2 & 0.2 & 0.01 & 0.01 & 0.01 & 0.01 & 0.01 & 0.0005 & 0.009 & 0.01 & 0.005 & 5.0 \\
\hline
\end{tabular}

Table 13. Leaching test results indicating the effect of clay minerals on the chelating effect (30 d).

\begin{tabular}{|c|c|c|c|c|c|c|c|c|c|c|c|c|}
\hline \multirow{2}{*}{ Sample } & \multicolumn{12}{|c|}{ Element (mg/L) } \\
\hline & $\mathrm{Na}$ & $\mathbf{K}$ & Ca & $\mathrm{Fe}$ & $\mathrm{Cu}$ & $\mathrm{Zn}$ & $\mathrm{Pb}$ & $\mathrm{Hg}$ & $\mathrm{Cd}$ & $\mathrm{Cr}$ & As & $\mathrm{Cl}^{-}$ \\
\hline Facility A TFA & 1500 & 2300 & 3100 & - & 0.05 & 0.01 & 0.05 & - & - & - & - & 9300 \\
\hline Facility A TFA + Zeolite 5\% & 1300 & 1800 & 1700 & - & - & - & - & - & - & - & - & 6300 \\
\hline Facility A TFA + Acid clay 5\% & 1300 & 1700 & 1300 & - & - & - & - & - & - & - & - & 6000 \\
\hline $\begin{array}{l}\text { Facility A TFA + Fukushima } \\
\text { vermiculite } 5 \%\end{array}$ & 1200 & 1700 & 2000 & - & - & - & - & - & - & - & - & 6200 \\
\hline $\begin{array}{c}\text { Facility A TFA + India } \\
\text { vermiculite } 5 \%\end{array}$ & 1200 & 1700 & 2100 & - & - & - & - & - & - & - & - & 6400 \\
\hline Zeolite & 16 & 1.9 & 46 & - & - & - & - & - & - & - & - & - \\
\hline Acid clay & 7.9 & 10 & 8.5 & - & - & - & - & - & - & - & - & 8.0 \\
\hline Fukushima vermiculite & 1.7 & 0.6 & 2.8 & - & - & - & - & - & - & - & - & - \\
\hline India vermiculite & 11 & 13 & 11 & - & - & - & - & - & - & - & - & 7.0 \\
\hline Quantification limit & 0.2 & 0.2 & 0.01 & 0.01 & 0.01 & 0.01 & 0.01 & 0.0005 & 0.009 & 0.01 & 0.005 & 5.0 \\
\hline
\end{tabular}

No significant changes were observed in the chelating effect upon direct addition and mixing of $5 \mathrm{wt}$.\% clay minerals. Moreover, no unusual heavy metal concentrations were observed in the leaching tests performed with only clay minerals. Therefore, it can be inferred that the direct addition and mixing of clay minerals did not interfere with the effect of chelating agents, and the inhibitory effect on heavy metal leaching was maintained. The $\mathrm{Cl}$ concentration increased with time in all the samples.

Previous research suggests that $C$ s leaching is caused by an increase in the concentrations of $\mathrm{K}, \mathrm{Na}$, or $\mathrm{Cl}$ in the surrounding areas (Cs leaching by ion exchange) [39-41]. Therefore, the gradual increase in r-Cs leaching rate with time in our study (Figures 5-7) may be attributed to the r-Cs captured by the clay minerals that leached out via ion exchange. In addition, $\mathrm{r}-\mathrm{Cs}$ leaching was more pronounced for FA and TFA than for BA during temporary storage and after landfilling. Furthermore, because of the strong alkalinity and high $\mathrm{Cl}$ concentration of the filtrate, possible corrosion and damage to concrete containers must be considered for long-term storage of FA and TFA. Based on these results, we recommend the direct addition and mixing of $5 \mathrm{wt} . \%$ clay minerals to inhibit the leaching of r-Cs from TFA without interfering with the effect of chelating agents. Some clay minerals can simultaneously inhibit $r-C s$ and heavy-metal leaching [42]. Therefore, the type of clay mineral can be defined to obtain this simultaneous inhibition.

The results indicating that the direct addition and mixing of clay minerals to both FA and TFA can inhibit the leaching of r-Cs suggest that clay minerals should be pre-mixed into slaked lime for the treatment of $\mathrm{HCl}$ gas and be simultaneously blown with slaked lime. Additional tanks and instruments for clay minerals should be obtained, and clay minerals should be direct added and mixing simultaneously with chelating agents in the chelation treatment. 
The method of pre-mixing slaked lime with clay minerals and simultaneously blowing clay minerals requires silos for the slaked lime (Figure 8), which are already installed in MSW incineration facilities. Therefore, hurdles associated with the introduction of this method are not high because the process utilizes structures that are already in place. However, the new process would require periodic inspections to check whether the piping is worn or the baghouse is deteriorated. In addition, to direct addition and mixing clay minerals together with chelators, a clay mineral direct addition and mixing system for the chelation treatment system should be constructed (Figure 9), and periodic inspections should also be conducted to investigate wear and damage in the chelation treatment system.

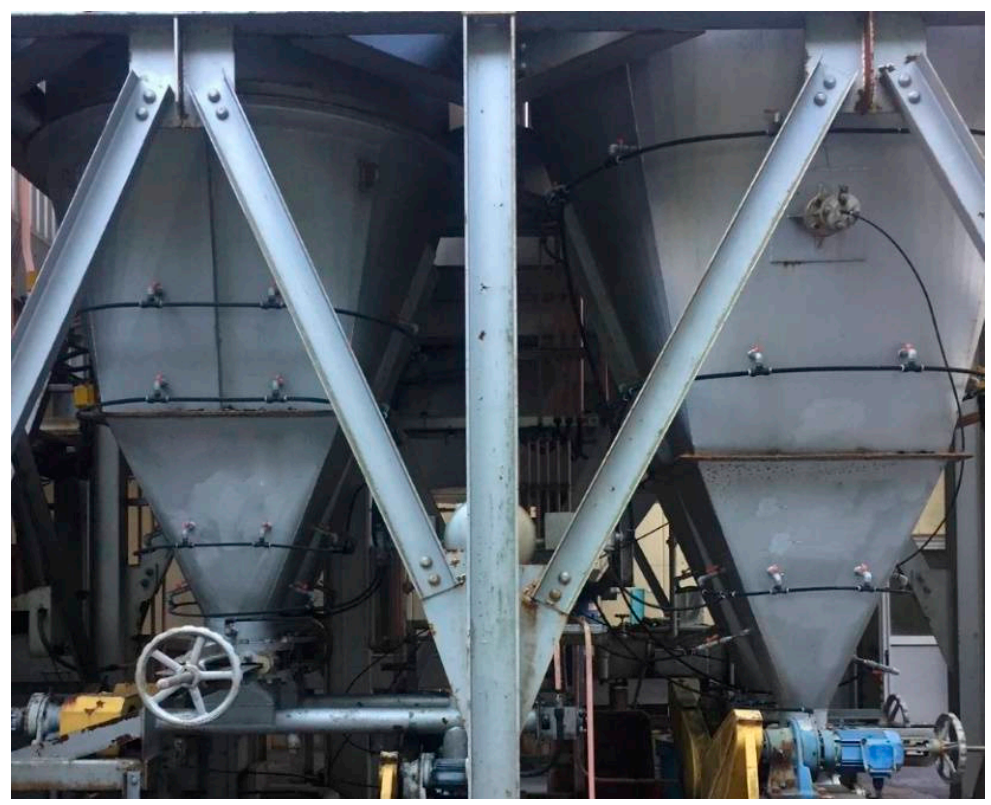

Figure 8. Silos for slaked lime in a municipal solid waste incineration facility.

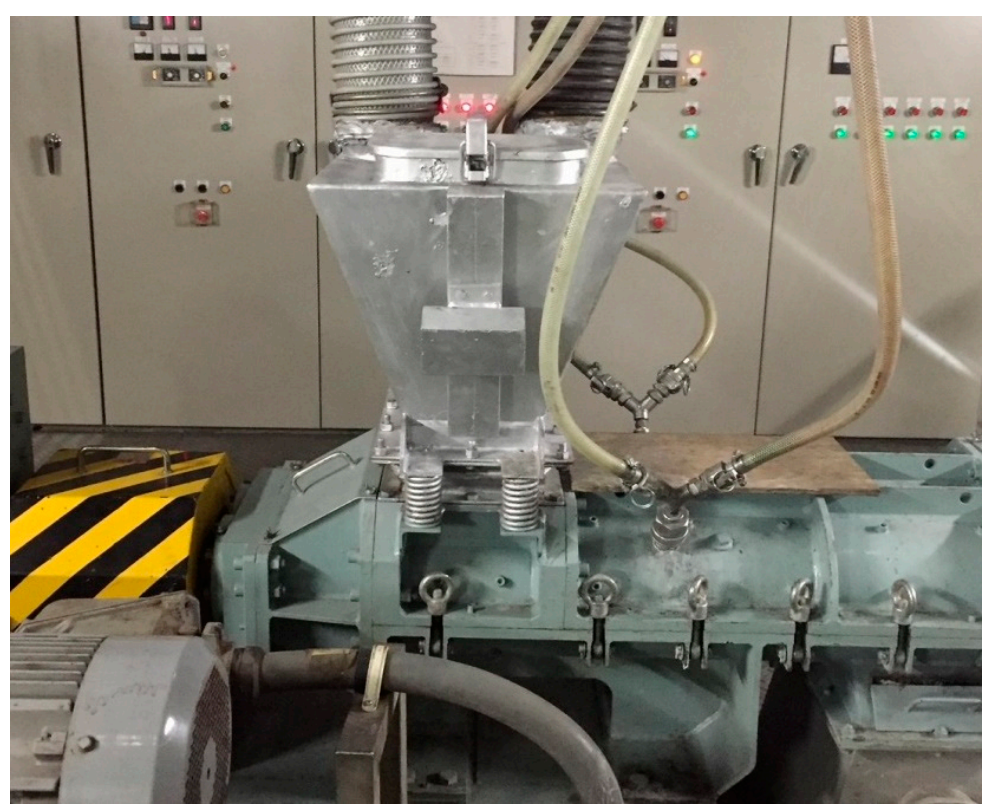

Figure 9. Chelation treatment system in a municipal solid waste incineration facility.

Finally, clay minerals can also be direct added and mixing to MSW incineration ash storage containers and when repacking waste into new containers during container inspection to improve the safety of long-term storage (e.g., Figure 4). 


\section{Conclusions}

Based on our experimental results, the following conclusions were made. First, the BA samples contained high concentrations of elements such as $\mathrm{Ca}, \mathrm{Si}$, and $\mathrm{Al}$, and the main components were $\mathrm{CaO}, \mathrm{SiO}_{2}$, and $\mathrm{Al}_{2} \mathrm{O}_{3}$. Conversely, the $\mathrm{FA}$ and TFA samples contained high concentrations of $\mathrm{Ca}, \mathrm{Cl}$, and $\mathrm{Na}$. The higher $\mathrm{Cl}$ content in FA than in $\mathrm{BA}$ suggested the high abundance of water-soluble chlorides in the former. Moreover, no significant changes in elemental composition were observed for different seasons within the same facility. In contrast, the r-Cs concentrations in BA, FA, and TFA showed substantial variation among the incineration facilities and between the seasons. FA and TFA presented higher r-Cs concentrations than BA in all the facilities. Moreover, both the filtrate r-Cs concentration and $\mathrm{r}-\mathrm{C}$ s leaching rate were higher in FA and TFA than in BA.

Second, it is difficult to prevent $r-C$ s leaching during recycling or landfilling using only chelating agents. Therefore, additional measures are required to inhibit $\mathrm{r}-\mathrm{Cs}$ leaching from FA and TFA, particularly from MSW incineration ash. The direct addition and mixing of clay minerals suppressed the leaching of r-Cs in all samples. In addition, the leaching inhibition was enhanced with increasing proportion (wt.\%) of clay minerals.

Third, no significant change was observed in the chelating effect upon direct addition and mixing of $5 \mathrm{wt} . \%$ clay minerals. Moreover, no unusual heavy metal concentrations were observed in the leaching test results performed on only clay minerals. Therefore, we concluded that the direct addition and mixing of clay minerals did not interfere with the effect of the chelating agents, and the inhibitory effect on heavy-metal leaching was maintained.

Therefore, we recommend the direct addition and mixing of clay minerals during the treatment of incinerated MSW to inhibit r-Cs leaching from FA, as they do not interfere with chelating agents. Moreover, clay minerals can be direct added and mixing to MSW incineration ash storage containers and when repacking waste into new containers during container inspection to improve safety during long-term storage.

Author Contributions: N.M.: Manuscript writing, data analysis, and interpretation; T.H.: Manuscript writing and designing the study. All authors participated in writing this paper. All authors have read and agreed to the published version of the manuscript.

Funding: This research received no external funding.

Institutional Review Board Statement: Not applicable.

Informed Consent Statement: Not applicable.

Conflicts of Interest: The authors declare no conflict of interest.

\section{References}

1. Hirose, K. 2011 Fukushima Dai-Ichi nuclear power plant accident: Summary of regional radioactive deposition monitoring results. J. Environ. Radioact. 2012, 111, 13-17. [CrossRef]

2. Emergency Operation Center; Ministry of Education, Culture, Sports, Science; Technology Agriculture, Forestry and Fisheries Research Council; Ministry of Agriculture, Forestry and Fisheries. Summarized Version of the "Results of the Research on Distribution of Radioactive Substances Discharged by the Accident at TEPCO's Fukushima Dai-ichi NPP". Available online: https:/ / radioactivity.nsr.go.jp/en/contents/1000/294/24/PressR04\%200802s.pdf (accessed on 22 July 2021).

3. Normile, D. Cooling a hot zone. Science 2013, 339, 1028-1029. [CrossRef]

4. Howard, B.J.; Beresford, N.A.; Hove, K. Transfer of radiocaesium to ruminants in natural and semi-natural ecosystems and appropriate counter measures. Health Phys. 1991, 61, 715-725. [CrossRef] [PubMed]

5. Ministry of the Environment of Japan. Solid Waste Management and Recycling Technology of Japan: Toward a Sustainable Society. Available online: http://www.env.go.jp/recycle/circul/venous_industry/en/brochure.pdf (accessed on 22 July 2021).

6. Ministry of the Environment of Japan. Environmental Remediation in Affected Areas in Japan. Available online: http://josen.env. go.jp/en/pdf/environmental_remediation_1905.pdf (accessed on 22 July 2021).

7. Iwahana, Y.; Ohbuchi, A.; Koike, Y.; Kitano, M.; Nakamura, T. Radioactive nuclides in the incinerator ashes of municipal solid wastes before and after the accident at the Fukushima nuclear power plant. Anal. Sci. 2013, 29, 61-66. [CrossRef]

8. Kuramochi, H.; Fujiwara, H.; Yui, K. Behavior of radioactive cesium during thermal treatment of radioactively contaminated wastes in the aftermath of the Fukushima Daiichi nuclear power plant accident. Glob. Environ. Res. 2016, $20,91-100$. 
9. Tsukada, H.; Takeda, A.; Hisamatsu, S.; Inaba, J. Concentration and specific activity of fallout ${ }^{137}$ Cs in extracted and particle-size fractions of cultivated soils. J. Environ. Radioact. 2008, 99, 875-881. [CrossRef] [PubMed]

10. Vandebroek, L.; Van Hees, M.; Delvaux, B.; Spaargaren, O.; Thiry, Y. Acid extraction as a predictive tool of Radiocaesium Interception Potential (RIP) in a worldwide scale. Radioprotection 2009, 44, 635-638. [CrossRef]

11. Namiki, Y.; Ueyama, T.; Yoshida, T.; Watanabe, R.; Koido, S.; Namiki, T. Hybrid micro-particles as a magnetically-guidable decontaminant for cesium-eluted ash slurry. Sci. Rep. 2014, 4, 6294. [CrossRef] [PubMed]

12. Li, Q.; Sun, Z.; Tao, D.; Xu, Y.; Li, P.; Cui, H.; Zhai, J. Immobilization of simulated radionuclide ${ }^{133} \mathrm{Cs}^{+}$by fly ash-based geopolymer. J. Hazard. Mater. 2013, 262, 325-331. [CrossRef]

13. Awual, M.R.; Yaita, T.; Taguchi, T.; Shiwaku, H.; Suzuki, S.; Okamoto, Y. Selective cesium removal from radioactive liquid waste by crown ether immobilized new class conjugate adsorbent. J. Hazard. Mater. 2014, 278, 227-235. [CrossRef] [PubMed]

14. Mallampati, S.R.; Mitoma, Y.; Okuda, T.; Sakita, S.; Simion, C. Preferential removal and immobilization of stable and radioactive cesium in contaminated fly ash with nanometallic Ca/CaO methanol suspension. J. Hazard. Mater. 2014, 279, 52-59. [CrossRef] [PubMed]

15. Ames, L.L., Jr. The cation sieve properties of clinoptilolite. Am. Miner. 1960, 45, 689-700.

16. El-Kamash, A.M. Evaluation of zeolite A for the sorptive removal of $\mathrm{Cs}^{+}$and $\mathrm{Sr}^{2+}$ ions from aqueous solutions using batch and fixed bed column operations. J. Hazard. Mater. 2008, 151, 432-445. [CrossRef]

17. Kogure, T.; Morimoto, K.; Tamura, K.; Sato, H.; Yamagishi, A. XRD and HRTEM evidence for fixation of cesium ions in vermiculite clay. Chem. Lett. 2012, 41, 380-382. [CrossRef]

18. Mukai, H.; Hirose, A.; Motai, S.; Kikuchi, R.; Tanoi, K.; Nakanishi, T.M.; Yaita, T.; Kogure, T. Cesium adsorption/desorption behavior of clay minerals considering actual contamination conditions in Fukushima. Sci. Rep. 2016, 6, 21543. [CrossRef]

19. Japanese Industrial Standards Committee. JIS K 0058-1, Test Methods for Chemicals in Slags. Part 1: Leaching Test Method; Japanese Standards Association: Tokyo, Japan, 2005. Available online: https://webdesk.jsa.or.jp/books/W11M0090/index/?bunsyo_id= JIS+K+0058-1\%3A2005 (accessed on 22 July 2021).

20. Yoon, I.-H.; Choi, W.-K.; Lee, S.-C.; Min, B.-Y.; Yang, H.-C.; Lee, K.-W. Volatility and leachability of heavy metals and radionuclides in thermally treated HEPA filter media generated from nuclear facilities. J. Hazard. Mater. 2012, 219-220, 240-246. [CrossRef] [PubMed]

21. Saffarzadeh, A.; Shimaoka, T.; Kakuta, Y.; Kawano, T. Cesium distribution and phases in proxy experiments on the incineration of radioactively contaminated waste from the Fukushima area. J. Environ. Radioact. 2014, 136, 76-84. [CrossRef] [PubMed]

22. Quina, M.J.; Santos, R.C.; Bordado, J.C.; Quinta-Ferreira, R.M. Characterization of air pollution control residues produced in a municipal solid waste incinerator in Portugal. J. Hazard. Mater. 2008, 152, 853-869. [CrossRef]

23. Weibel, G.; Eggenberger, U.; Schlumberger, S.; Mäder, U.K. Chemical associations and mobilization of heavy metals in fly ash from municipal solid waste incineration. Waste Manag. 2017, 62, 147-159. [CrossRef]

24. Zhu, F.; Takaoka, M.; Shiota, K.; Oshita, K.; Kitajima, Y. Chloride chemical form in various types of fly ash. Environ. Sci. Technol. 2008, 42, 3932-3937. [CrossRef]

25. Bogush, A.; Stegemann, J.A.; Wood, I.; Roy, A. Element composition and mineralogical characterisation of air pollution control residue from UK energy-from-waste facilities. Waste Manag. 2015, 36, 119-129. [CrossRef] [PubMed]

26. Hartmann, S.; Koval, L.; Škrobánková, H.; Matýsek, D.; Winter, F.; Purgar, A. Possibilities of municipal solid waste incinerator fly ash utilisation. Waste Manag. Res. 2015, 33, 740-747. [CrossRef]

27. Cogin, G.E.; Kimball, G.E. The vapor pressures of some alkali halides. J. Chem. Phys. 1948, 16, 1035-1048. [CrossRef]

28. Scheer, M.D.; Fine, J. Entropies, heats of sublimation, and dissociation energies of the cesium halides. J. Chem. Phys. 1962, 36, 1647-1653. [CrossRef]

29. Yui, K.; Kuramochi, H.; Osako, M. Understanding the behavior of radioactive cesium during the incineration of contaminated municipal solid waste and sewage sludge by thermodynamic equilibrium calculation. ACS Omega 2018, 3, 15086-15099. [CrossRef] [PubMed]

30. Ohbuchi, A.; Fujii, K.; Kasari, M.; Koike, Y. Characterization of soluble and insoluble radioactive cesium in municipal solid waste incineration fly ash. Chemosphere 2020, 248, 126007. [CrossRef]

31. Fujiwara, H.; Kuramochi, H.; Maeseto, T.; Nomura, K.; Takeuchi, Y.; Kawamoto, K.; Yamasaki, S.; Kokubun, K.; Osako, M. Influence of the type of furnace on behavior of radioactive cesium in municipal solid waste thermal treatment. Waste Manag. 2018, 81, 41-52. [CrossRef]

32. Yang, H.-C.; Eun, H.-C.; Lee, D.-G.; Oh, W.-Z.; Lee, K.-W. Behavior of radioactive elements during thermal treatment of nuclear graphite waste thermodynamic model analysis. J. Nuclear Sci. Technol. 2005, 42, 869-876. [CrossRef]

33. Yoo, J.-I.; Shinagawa, T.; Wood, J.P.; Linak, W.P.; Santoianni, D.A.; King, C.J.; Seo, Y.-C.; Wendt, J.O.L. High-temperature sorption of cesium and strontium on dispersed kaolinite powders. Environ. Sci. Technol. 2005, 39, 5087-5094. [CrossRef]

34. Kouvo, P.; Backman, R. Estimation of trace element release and accumulation in the sand bed during bubbling fluidised bed co-combustion of biomass, peat, and refuse-derived fuels. Fuel 2003, 82, 741-753. [CrossRef]

35. Suriyawong, A.; Magee, R.; Peebles, K.; Biswas, P. Energy recycling by co-combustion of coal and recovered paint solids from automobile paint operation. J. Air Waste Manag. Assoc. 2009, 59, 560-567. [CrossRef] 
36. Parajuli, D.; Tanaka, H.; Hakuta, Y.; Minami, K.; Fukuda, S.; Umeoka, K.; Kamimura, R.; Hayashi, Y.; Ouchi, M.; Kawamoto, T. Dealing with the aftermath of Fukushima Daiichi nuclear accident: Decontamination of radioactive cesium enriched ash. Environ. Sci. Technol. 2013, 47, 3800-3806. [CrossRef] [PubMed]

37. Kozai, N.; Suzuki, S.; Aoyagi, N.; Sakamoto, F.; Ohnuki, T. Radioactive fallout cesium in sewage sludge ash produced after the Fukushima Daiichi nuclear accident. Water Res. 2015, 68, 616-626. [CrossRef] [PubMed]

38. Fujiwara, H.; Kuramochi, H.; Nomura, K.; Maeseto, T.; Osako, M. Behavior of radioactive cesium during incineration of radioactively contaminated wastes from decontamination activities in Fukushima. J. Environ. Radioact. 2017, 178-179, 290-296. [CrossRef] [PubMed]

39. Cremers, A.; Elsen, A.; De Preter, P.; Maes, A. Quantitative analysis of radiocaesium retention in soils. Nature 1988, 335, $247-249$. [CrossRef]

40. Gommers, A.; Thiry, Y.; Delvaux, B. Rhizospheric mobilization and plant uptake of radiocesium from weathered micas: I. Influence of potassium depletion. J. Environ. Qual. 2005, 34, 2167-2173. [CrossRef]

41. Thiry, Y.; Gommers, A.; Iserentant, A.; Delvaux, B. Rhizospheric mobilization and plant uptake of radiocesium from weathered micas: II. Influence of mineral alterability. J. Environ. Qual. 2005, 34, 2174-2180. [CrossRef]

42. Otunola, B.O.; Ololade, O.O. A review on the application of clay minerals as heavy metal adsorbents for remediation purposes. Environ. Technol. Innov. 2020, 18, 100692. [CrossRef] 